\title{
Regional-scale transport of air pollutants: impacts of Southern California emissions on Phoenix ground-level ozone concentrations
}

\author{
J. Li ${ }^{1}$, M. Georgescu ${ }^{1,2}$, P. Hyde ${ }^{3}$, A. Mahalov ${ }^{1}$, and M. Moustaoui ${ }^{1}$ \\ ${ }^{1}$ Julie Ann Wrigley Global Institute of Sustainability, School of Mathematical and Statistical Sciences, \\ Arizona State University, Tempe, AZ 85287, USA \\ ${ }^{2}$ School of Geographical Sciences and Urban Planning, Arizona State University, Tempe, AZ 85287, USA \\ ${ }^{3}$ School for Engineering of Matter, Transport and Energy, Arizona State University, Tempe, AZ 85287, USA \\ Correspondence to: J. Li (jialun.li@asu.edu)
}

Received: 15 January 2015 - Published in Atmos. Chem. Phys. Discuss.: 19 March 2015

Revised: 4 June 2015 - Accepted: 2 August 2015 - Published: 21 August 2015

\begin{abstract}
In this study, WRF-Chem is utilized at high resolution $(1.333 \mathrm{~km}$ grid spacing for the innermost domain) to investigate impacts of southern California anthropogenic emissions (SoCal) on Phoenix ground-level ozone concentrations $\left(\left[\mathrm{O}_{3}\right]\right)$ for a pair of recent exceedance episodes. First, WRFChem control simulations, based on the US Environmental Protection Agency (EPA) 2005 National Emissions Inventories (NEI05), are conducted to evaluate model performance. Compared with surface observations of hourly ozone, $\mathrm{CO}$, $\mathrm{NO}_{X}$, and wind fields, the control simulations reproduce observed variability well. Simulated $\left[\mathrm{O}_{3}\right]$ are comparable with the previous studies in this region. Next, the relative contribution of SoCal and Arizona local anthropogenic emissions (AZ) to ozone exceedances within the Phoenix metropolitan area is investigated via a trio of sensitivity simulations: (1) SoCal emissions are excluded, with all other emissions as in Control; (2) AZ emissions are excluded with all other emissions as in Control; and (3) SoCal and AZ emissions are excluded (i.e., all anthropogenic emissions are eliminated) to account only for Biogenic emissions and lateral boundary inflow (BILB). Based on the USEPA NEI05, results for the selected events indicate the impacts of $\mathrm{AZ}$ emissions are dominant on daily maximum $8 \mathrm{~h}$ average (DMA8) $\left[\mathrm{O}_{3}\right]$ in Phoenix. SoCal contributions to DMA8 $\left[\mathrm{O}_{3}\right]$ for the Phoenix metropolitan area range from a few ppbv to over $30 \mathrm{ppbv}$ (10-30\% relative to Control experiments). $\left[\mathrm{O}_{3}\right]$ from SoCal and $\mathrm{AZ}$ emissions exhibit the expected diurnal characteristics that are determined by physical and photochemical processes, while BILB contributions to DMA8 $\left[\mathrm{O}_{3}\right]$ in Phoenix also play a key role.
\end{abstract}

Finally, ozone transport processes and pathways within the lower troposphere are investigated. During daytime, pollutants (mainly ozone) near the Southern California coasts are pumped into the planetary boundary-layer over the Southern California desert through the mountain chimney and pass channel effects, aiding eastward transport along the desert air basins in southern California and finally, northeastward along the lower Gila River basin in Arizona, thereby affecting Phoenix air quality during subsequent days. This study indicates that local emission controls in Phoenix need to be augmented with regional emission reductions to attain the federal ozone standard, especially if a more stringent standard is adopted in the future.

\section{Introduction}

Tropospheric ozone is a strong oxidant controlling much of the chemistry in the atmosphere, such as hydroxyl radical production and the lifetime of atmospheric species (see review in He et al., 2013). Tropospheric ozone is also a greenhouse gas and acts as an important anthropogenic contributor to radiative forcing of climate (IPCC, 2007). Lower tropospheric ozone adversely affects human health (Anderson, 2009; Smith et al., 2009), reduces crop yields (Avnery et al., 2011; Chameides et al., 1999), and damages natural ecosystems (Ashmore, 2005; Mauzerall and Wang, 2001). Therefore, ozone $\left(\mathrm{O}_{3}\right)$ is one of the six criteria pollutants regulated by the US Environmental Protection Agency (EPA) through National Ambient Air Quality Standards (NAAQS). 
The current NAAQS for $\mathrm{O}_{3}$ concentrations $\left(\left[\mathrm{O}_{3}\right]\right)$ is $75 \mathrm{ppbv}$, defined as the 3-year average of the annual fourth-highest daily maximum 8 -h average (DMA8) $\left[\mathrm{O}_{3}\right]$ for each monitoring site within an airshed. The US EPA has already proposed to lower the standard to 65-70 ppbv (EPA, 2014) and may also redefine the national $\mathrm{O}_{3}$ secondary standard for protecting sensitive vegetation and ecosystems (Huang et al., 2013). Currently, many US cities are classified as NAAQS $\mathrm{O}_{3}$ nonattainment areas based on the 2008 federal standard (http://www.epa.gov/airquality/greenbook/hnc.html). In addition, sensitive areas (e.g., national parks and wilderness areas) also experience DMA8 $\mathrm{O}_{3}$ exceedances (http://www. nature.nps.gov/air/Monitoring/exceed.cfm). Therefore, improved understanding and attribution of $\left[\mathrm{O}_{3}\right]$ sources in these areas is necessary to develop effective air quality management strategies to achieve ever more stringent US air quality standards.

As a secondary pollutant, measured ground-level $\left[\mathrm{O}_{3}\right]$ is the result of $\mathrm{O}_{3}$ production/loss due to local sources of precursor emissions, to transport of $\mathrm{O}_{3}$ and its precursors from nearby and/or remote regions, and to ozone formed from natural precursor emissions. The direct way to characterize $\mathrm{O}_{3}$ source attribution is through field measurements (e.g., Fast et al., 2002; Kemball-Cook et al., 2009; Nunnermacker et al., 2004). The other way to identify transported $\mathrm{O}_{3}$ and local generated $\mathrm{O}_{3}$ is to use trajectory models (e.g., MacDonald et al., 2006; Lanford et al., 2010).

Transport of ozone and its precursors from one area to another is determined by flow patterns, which can be obtained by measurement and/or modeling. However, information on flow alone is insufficient in ozone studies because of the complexity of the chemistry involved, wherein ozone and precursors nonlinearly interact with flow, turbulence and sunlight to determine ozone distributions (Huang et al., 2013; Lee et al., 2003, 2007; Levy II et al., 1985). Chemical transport models (CTMs) are increasingly common in simulating atmospheric chemical and transport processes at regional/continental/global scales because of the detailed physical and chemical processes which they are capable of simulating. For example, using a CTM (GFDL AM3), Lin et al. (2012) found that $\mathrm{Asian} \mathrm{O}_{3}$ pollutants can affect surface $\left[\mathrm{O}_{3}\right]$ in the western US, contributing up to $8-15 \mathrm{ppbv}$ to the DMA8; and that Asian pollution increases the DMA8 $\mathrm{O}_{3}$ exceedance days by $53 \%$ in the southwestern US. Huang et al. (2013) combining model simulations at $12 \mathrm{~km}$ resolution (WRF/STEM), remote-sensing, and ground-based observations, have studied the effect of Southern California anthropogenic emissions (SoCal) on ozone pollution in southwestern US mountain states. They found that the SoCal precursor emissions and its transported ozone increased $\left[\mathrm{O}_{3}\right]$ up to $15 \mathrm{ppbv}$ in western Arizona. They also characterized the nonlinear relationship between emissions and $\left[\mathrm{O}_{3}\right]$. However, these studies have not examined the impacts of regional emissions on $\left[\mathrm{O}_{3}\right]$ in an urban setting (such as Phoenix), at high resolution.
Physical/chemical-based CTM modeling is the only available tool for ozone transport predictions on finer spatial scales (Lee et al., 2007). Many studies have investigated ozone transport at urban scales using coupled meteorological and chemistry models. For example, Lu et al. (1997) found that ozone and other pollutant concentrations were higher in northern and eastern Los Angeles (LA) than those in the western and central greater LA, where strong emission sources are located, due to transport owing to the persistent onshore sea breeze and mountain-induced upslope flow. Analogously, that surface $\left[\mathrm{O}_{3}\right]$ in the Phoenix metropolitan area and its rural environs are higher in northeastern than in southwestern Phoenix arises from transport of urban pollutants by prevailing southwest winds (Fast et al., 2000; Lee et al., 2003, 2007; Lee and Fernando, 2013). Although these studies have considered both chemistry and transport processes at the urban scale, they did not try to distinguish between ozone produced by local emissions and that produced by regional transport, a principal motivation of this study.

The Phoenix metropolitan area is classified as an $\mathrm{O}_{3}$ nonattainment area under the 2008 NAAQS primary $\mathrm{O}_{3}$ standard (http://www.epa.gov/airquality/greenbook/hnc. $\mathrm{html})$. Therefore, it is helpful to separately quantify the relative contributions of local emissions and regional transport to Phoenix $\left[\mathrm{O}_{3}\right]$ in order to design feasible and effective ozone control strategies. Both aircraft observations (Nunnermacker et al., 2004) and backward trajectory analysis (MacDonald et al., 2006) indicate that surface $\left[\mathrm{O}_{3}\right]$ on exceedance days are attributed to both Arizona local anthropogenic emissions (AZ) and regional and/or continental transport. Therefore, our focus is to use a CTM to separately quantify the contributions of local and regional emissions to the ozone distributions in Phoenix on exceedance days, research which has not been published in peer-reviewed journals.

In addition, previous studies indicate that coarseresolution modeling cannot adequately represent the heterogeneities of ozone and meteorological fields in Phoenix due to its complex terrain (Fast et al., 2000; Lee et al., 2003; Lee and Fernando, 2013). That high-resolution CTMs can obtain better results in modeling urban air quality is also reported for the LA basin, Mexico City, and other regions (e.g., Tie et al., 2010; Chen at al., 2013; Lu and Turco, 1995, 1996; Taha, 2008; Klich and Fuelberg, 2014; Stock et al., 2014). Therefore, employing a high-resolution CTM to address air pollutant distributions in the Phoenix metropolitan area due to local emissions and regional transport is our second motivation.

Using WRF-Chem (Grell et al., 2005) at high resolution, we will examine the following: (1) the relative contributions of SoCal and AZ to the ozone episodes in Phoenix, and (2) how SoCal (emissions) affect Phoenix $\left[\mathrm{O}_{3}\right]$. This is a topic that has received limited research attention to date (Moore, 2014), but requires investigation because of the metropolitan area's non-attainment ozone status and because of the need to evaluate the effectiveness of local an- 
thropogenic emission control strategies necessary to attain the standard.

\section{Methodology}

\subsection{WRF-Chem setup}

We chose WRF-Chem (version 3.5.1) as the CTM since it has been successfully used in this region (Chen et al., 2013; Li et al., 2014; Zhao et al., 2012). In WRF-Chem, the Weather Research and Forecasting (WRF) model (Skamarock et al., 2008) is employed to resolve atmospheric physics and dynamical processes, while the coupled chemistry (Chem) model is used to simulate chemical processes such as gaseous and aqueous chemical reactions, dispersion, and deposition. The WRF-Chem setup consists of the Lin's cloud scheme (Lin et al., 1983), the RRTM radiation scheme (Mlawer et al., 1997), the Noah land surface model with single layer urban canopy model (Chen and Dudhia, 2001; Chen et al., 2011; Ek et al., 2003), the Grell-Devenyi ensemble cumulus scheme (Grell and Devenyi, 2002) that allows subsidence and spreading at high resolution, a revised MM5 surface layer, and the BouLac Planetary Boundary Layer (PBL) schemes. Land cover and land use data from the MODIS $1 \mathrm{~km}$ resolution data set (Friedl et al., 2002) are combined with the 2006 National Land Cover Database (NLCD) 3-class urban covers to better represent the urban landscape. The second generation regional acid deposition model (RADM2, Stockwell et al., 1990; Gross and Stockwell, 2003) is used for gas-phase chemical reactions. The aerosol algorithms are based on the MADE/SORGAM (Ackermann et al., 1998; Schell et al., 2001) with GOCART, functioning as an emission scheme that accounts for surface wind speed, soil moisture, and soil erodibility (Ginoux et al., 2001; Zhao et al., 2010). The other selected chemistry schemes are based on the recommendations provided in the WRF-Chem users' guide (Peckam et al., 2013).

Four nested domains are used (Fig. 1a). The first (domain 1) has $36 \mathrm{~km}$ grid spacing and covers the western and central US, eastern Pacific, northern and central Mexico, the Gulf of California, and the western Gulf of Mexico. Nested domains 2,3 , and 4 use grid spacings of 12,4 , and $1.333 \mathrm{~km}$, respectively. The innermost domain $(1.333 \mathrm{~km}$ grid spacing with 640 by 301 grid cells) encompasses Southern California (the South Coast Air Basin or greater Los Angeles Air Basin, the San Diego Air Basin, the southern Mojave Desert Air Basin, the Salton Sea Air Basin, the southern part of the South Central Air Basin), and the central and southern Arizona airsheds to better represent the complex terrain and land cover features (see Fig. 1b). As shown in Fig. 1b, the mountainous features in southern California and Arizona are well represented at high resolution. The San Gorgonio Pass (between the San Bernardino Mountains and the San Jacinto Mountains), the Cajon Pass (between the San Gabriel Mountains
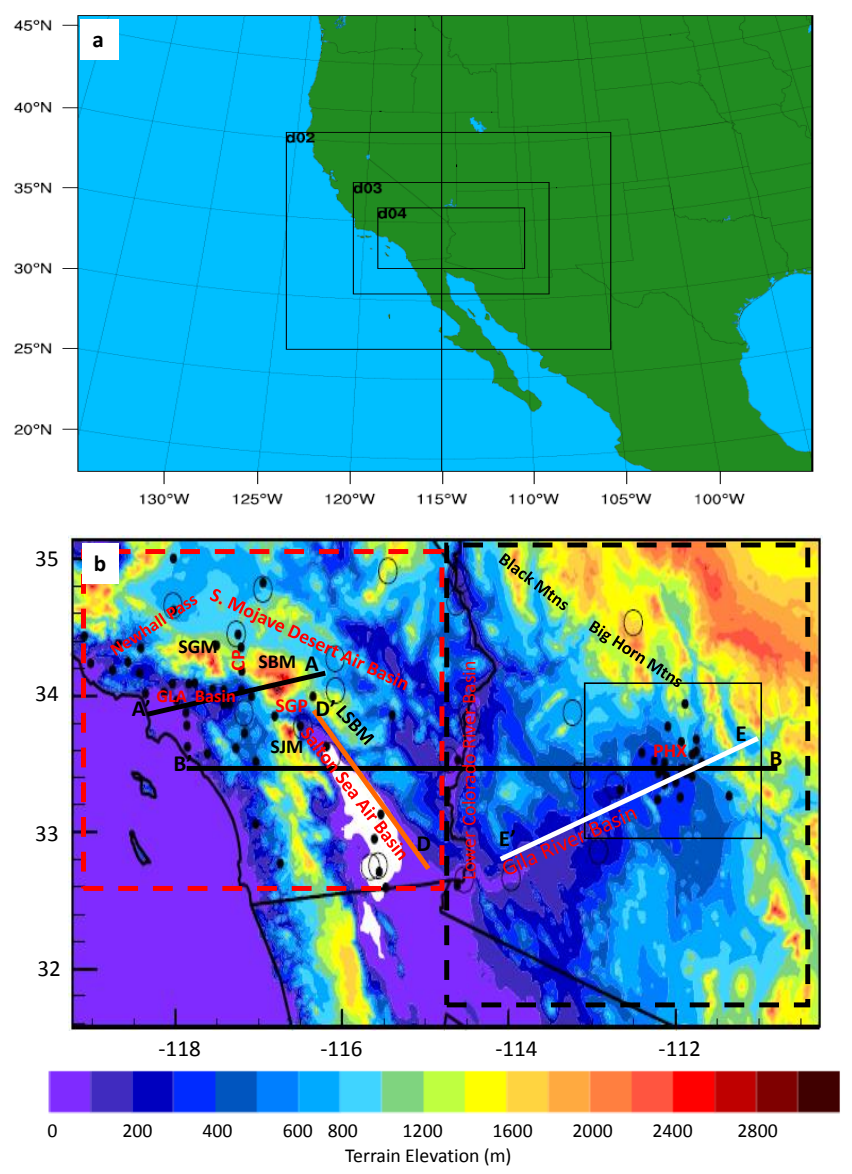

Figure 1. (a) 4-nested model domains-D01 to D04, from the largest rectangle box to the smallest rectangle box. (b) Innermost domain terrain elevation (m). Black dots indicate the locations of $\mathrm{CO}, \mathrm{NO}_{x}$, and/or $\mathrm{O}_{3}$ observation sites. Circles represent surface wind observation sites. Red-dashed-line box shows the southern California and black-dashed-line box stands for southern and central Arizona. SGM stands for the San Gabriel Mountains; SBM indicates the San Bernardino Mountains; LSBM indicates the Little San Bernardino Mountains; SJM represents the San Jacinto Mountains. SGP stands for the San Gorgonio Pass, between SBM to the north and SJM to the south. CP represents the Cajon Pass between SGM to the west and SBM to the east. PHX stands for Phoenix metropolitan area. Lines A'A, B'B, D'D, and E'E are cross-section locations and are discussed in text and Figs. 8, 10, 13 and 14, respectively.

and the San Bernardino Mountains), and the Newhall Pass (west of the San Gabriel Mountains) are also resolved. The vertical configuration of the model comprised 41 layers: the lowest 15 layers are within $1500 \mathrm{~m}$ a.g.l. and the first halfvertical layer above the land surface is at $12.5 \mathrm{~m}$ a.g.l. The observation sites (including $\mathrm{O}_{3}, \mathrm{NO}_{x}, \mathrm{CO}$, and surface wind observations) used for validation of the control simulations are also superimposed (Fig. 1b). 


\subsection{Data used for model initialization and evaluation}

The biogenic emission data are obtained from the $1 \mathrm{~km}$ resolution Model of Emissions of Gases and Aerosols from Nature (MEGAN, Guenther et al., 2006). The North American Regional Reanalysis (NARR; Mesinger et al., 2006) product is used for initial and boundary conditions (atmospheric and land surface [e.g., soil moisture and temperature]). NARR data are distributed on a $32 \mathrm{~km}$ grid with a $3 \mathrm{~h}$ temporal frequency. The atmospheric chemical boundary and initial conditions are obtained from MOZART-4/GEOS-5 (http://www.acd.ucar.edu/wrf-chem/mozart.shtml) for 2012 case and MOZART-4/NCEP T42 for 2005 case (Emmons et al., 2010).

The anthropogenic emissions used in this study are obtained from 2005 National Emissions Inventories (NEI05) data provided by the US EPA (www.epa.gov/ttnchie1/net/ 2005inventory.html). These data are distributed on a $4 \mathrm{~km}$ grid array covering the US and surrounding land areas. A method utilized to interpolate the $4 \mathrm{~km}$ grid spacing NEI05 data to any resolution one wishes to use for WRF-Chem simulations is provided with the WRF-Chem system (http:// www.acd.ucar.edu/wrf-chem/). Each WRF-Chem model grid point data is based on averaging from those NEI05 grid points that fall within a distance less than the WRF-Chem model resolution. The method works well when WRF-Chem grid spacing is coarser than $4 \mathrm{~km}$. However, the method misrepresents emissions when the model resolution is greater than the NEI05 grid. To overcome this issue, we have used Monotonic Cubic Interpolation to downscale the $4 \mathrm{~km}$ resolution NEI05 data to a $1.333 \mathrm{~km}$ resolution grid (the finest model grid spacing of our WRF-Chem simulations). Details on the NEI05 downscaling method and improved simulation performance are discussed separately (Li et al., 2014).

The data used for model evaluation include measurements of surface wind speed and direction (24 sites within Domain 4). These wind fields are obtained from two networks: the AZMET (ag.arizona.edu/azmet), and the Air Quality and Meteorological Information System (AQMIS) in the California EPA/Air Resources Board (www.arb.ca.gov/aqmis2/ aqmis2.php). We use hourly observations of ozone concentrations from 26 stations in Arizona (downloaded from www. epa.gov/ttn/airs/airsaqs/) and 46 stations in Southern California (downloaded from www.arb.ca.gov/aqmis2/aqdselect. php?tab=hourly). In addition, the hourly $\mathrm{NO}_{x}$ observations, including four stations in Arizona and over 20 sites in Southern California, and hourly $\mathrm{CO}$ observations, including four stations in Arizona and about 20 stations in Southern California, can be obtained from the same websites as ozone data. Comparison of simulated and observed VOC concentrations was precluded by the latter's irregular availability and their lack of hourly concentrations.
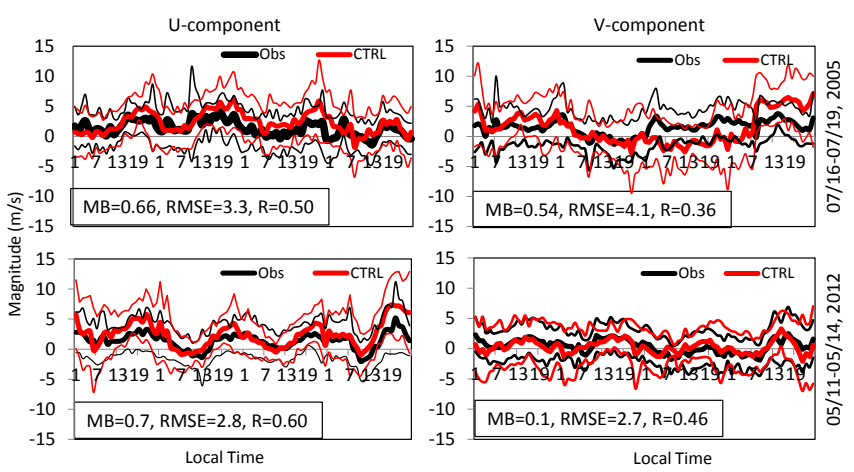

Figure 2. Surface wind comparisons between simulations (boldred) and observations (bold black). There are 20 sites in total, including those in CA and AZ with locations shown in Fig. $1 \mathrm{~b}$ as circles. The variation ranges of simulation and observation are correspondingly labeled by thin-red-line and thin-black-line, respectively. Mean Biases (MB), RMSE and correlation coefficient $(R)$ are labeled also. CTRL represents WRF-Chem control run.

\section{Results and discussion}

Two episodes (14 May 2012 and 19 July 2005) are selected as case studies. The criterion for selection required observed DMA8 $\left[\mathrm{O}_{3}\right]$ to exceed $80 \mathrm{ppbv}$ for at least 10 of the reporting stations in the Phoenix metropolitan area. For both events, the synoptic weather in Southern California and south-central Arizona was calm, clear, and sunny with light westerly winds within the lower troposphere for the time periods discussed in this section, based on NARR 3-hourly data. In addition, these two events represent the pre-monsoon and monsoon seasons, respectively, two typical climate circulations (Adams and Comrie, 1997) during the ozone season.

The model (WRF-Chem) is initialized 4 days prior to each episode with the data of the first $24 \mathrm{~h}$ being discarded. In addition, analysis nudging is applied for the meteorological fields $(U, V, T, \mathrm{GPH}$, and $Q)$ above the PBL in the outermost domain for the first $24 \mathrm{~h}$.

\subsection{Model evaluation}

Figure 2 shows the comparison of surface wind fields (circles in Fig. 1b) between observations (bold-black) and WRFChem simulations (bold-red; i.e., running WRF-Chem with appropriate emissions and hereafter referred to as CTRL) for the selected events. The time periods (labeled in Fig. 2) cover 4 days, concluding with the episode day in the Phoenix metropolitan area. In comparison with observations, the model appropriately reproduced the diurnal variation with only a slight overestimate of wind speed during daytime. Note that each observation represents a single point while the closest simulation grid cell to the observed latitude/longitude location (representing an area of 1.333 by $1.333 \mathrm{~km}$ ) is used for comparison. Although there are some differences be- 
tween simulated and observed means, the standard deviations for both modeled (thin-red) and observed (thin-black) measurements fall in the same range. Mean Bias (MB), Root Mean Squared Error (RMSE), and correlation coefficient $(R)$ are also calculated and labeled in each panel. For the $U$ component of wind speed, MB is less than $1.0 \mathrm{~m} \mathrm{~s}^{-1}$ and RMSE is about $3.0 \mathrm{~m} \mathrm{~s}^{-1}$ (indicating wind heterogeneity within the simulation domain). $U$ component winds for the CTRL runs and the observations exhibit linear correlations with statistical significance $(P<0.01)$. The MB for $V$ component wind is less than $0.5 \mathrm{~m} \mathrm{~s}^{-1}$. Linear correlation indicates that $V$ component winds from the model and the observations are statistically significant $(P<0.01)$ for the time periods of 11-14 May 2012 and 16-19 July 2005. The wind and temperature comparisons between WRF-Chem in Domain 1 and NARR data are also examined. Generally, the simulations are consistent with NARR data in patterns and magnitudes for the two cases. More specifically, there were continuously westerly winds between southern California and central Arizona for both NARR and simulations at $850 \mathrm{hPa}$. Figure $\mathrm{S} 1$ in the Supplement is an example of the comparisons of wind and temperature at $850 \mathrm{hPa}$ (bottom panel) and $700 \mathrm{hPa}$ (top panel) for the average of 16-19 July 2005. These comparisons, which indicate sufficiently accurate meteorological simulations, ensure that regional pollutant transport can be adequately simulated, one of our focuses in this study.

Figure 3 shows the comparison of $\mathrm{CO}, \mathrm{NO}_{x}$, and $\mathrm{O}_{3}$ concentrations between the model (bold-red, i.e., CTRL run) and observations (bold-black) in Domain 4 for the same time periods. Note that only four sites of $\mathrm{NO}_{x}$ and $\mathrm{CO}$ were measured (only one site online available) in greater Phoenix while over 20 sites are found in Southern California. On average, the model performed well for both $\mathrm{CO}$ and $\mathrm{NO}_{x}$ concentrations for the July case. In contrast, for the May case, the model overestimated $\mathrm{CO}$ and $\mathrm{NO}_{x}$ during nighttime but matched observations during daytime. The standard deviations (thin-red) from the model are much greater than those from observations (thin-black), indicating that modeled $\mathrm{NO}_{x}$ and $\mathrm{CO}$ heterogeneity at sites is greater than that from observations. The model behavior in the May case indicates that the anthropogenic emissions could be over-estimated using the NEI05 data due to emission control strategies enacted in California in the seven intervening years (Pusede and Cogen, 2012). Figure S2 shows how the emissions changed between 2005 and 2012 for the South Coast Air Basin, California (http://www.arb.ca. gov/app/emsinv/fcemssumcat2013.php) and 2011 in Maricopa County, Arizona (http://maricopa.gov/aq/divisions/ planning_analysis/emissions_inventory/Default.aspx) Relative to 2005, anthropogenic emissions of $\mathrm{CO}, \mathrm{NO}_{x}$, and VOC are reduced about 40-50\% in 2012 in the South Coast airshed, California. Therefore, the NEI 2005 overestimates $[\mathrm{CO}]$ and $\left[\mathrm{NO}_{x}\right]$. However, the changes in Maricopa County are not significant except $\mathrm{CO}$ from Mobile.
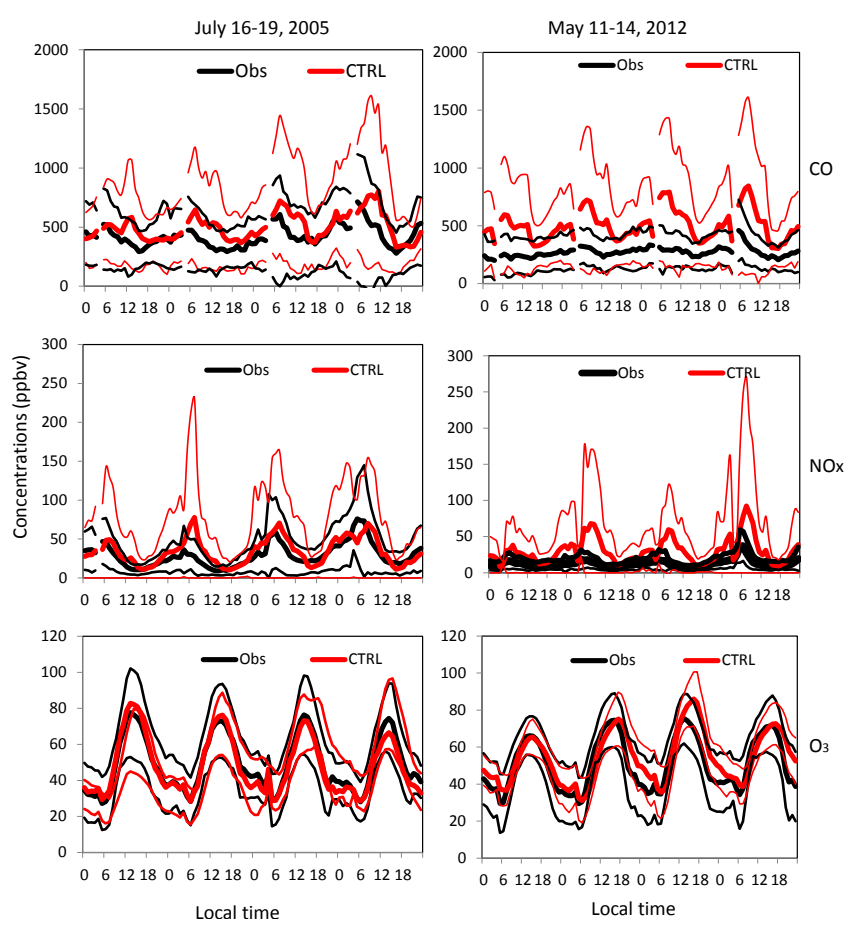

Figure 3. The comparisons of $\mathrm{CO}, \mathrm{NO}_{x}$, and $\mathrm{O}_{3}$ concentrations between observations (bold black) and simulations (bold red) in Domain 4 . There are 23 sites for $\mathrm{NO}_{x}, 20$ sites for $\mathrm{CO}$, and 65 sites for $\mathrm{O}_{3}$ observations during the study time periods. The locations are shown in Fig. 1b. The variation ranges of simulation and observation are correspondingly labeled by thin-red-line and thin-blackline, respectively. Missing observation time (04:00 local time) is masked in the figure. CTRL represents WRF-Chem control run.

The $\left[\mathrm{O}_{3}\right]$ comparison between observations and simulations presented in Fig. 3 indicates the model performed better in simulating $\left[\mathrm{O}_{3}\right]$ than $\mathrm{CO}$ or $\mathrm{NO}_{x}$. Both the station average and station standard deviation from the model and observations matched each other on event and non-event days (details on site-by-site comparisons in Phoenix will be discussed in the next section). The simulated average $\left[\mathrm{O}_{3}\right]$ and their spatial heterogeneities fall within the range of observations except on 13 May 2012, when modeled average $\left[\mathrm{O}_{3}\right]$ and the spatial standard deviations fall out of the observation ranges.

Figure $\mathrm{S} 3$ shows $\left[\mathrm{O}_{3}\right]$ time series separately for Southern California and greater Phoenix; corresponding statistics are shown in Table 1. In checking Fig. 3, and Figs. S2 and S3, although the NEI-2005 over-estimated $\mathrm{CO}$ and $\mathrm{NO}_{x}$ emissions in 2012 in the south coast airshed, California, causing $\left[\mathrm{NO}_{x}\right]$ and $[\mathrm{CO}]$ to be over-estimated as well, the ozone simulations nonetheless appear to be quite acceptable. One explanation could be that this airshed is categorized as a VOClimited ozone environment. Under this condition, ozone concentrations are restrained by VOC concentrations. In other words, reducing $\mathrm{NO}_{x}$ fails to reduce ozone concentrations (e.g., Taha et al., 1998) and the same is also found in Phoenix 
Table 1. Statistical results of hourly ozone concentrations of WRF-Chem simulations (CTRL) at 1 and $4 \mathrm{~km}$ resolution.

\begin{tabular}{|c|c|c|c|c|c|c|c|c|}
\hline & \multicolumn{4}{|c|}{ 11-14 May 2012} & \multicolumn{4}{|c|}{ 16-19 July 2015} \\
\hline & $\begin{array}{r}\mathrm{CA} \\
1 \mathrm{~km}\end{array}$ & $\begin{array}{r}\text { CA } \\
4 \mathrm{~km}\end{array}$ & $\begin{array}{r}\mathrm{AZ} \\
1 \mathrm{~km}\end{array}$ & $\begin{array}{r}\text { AZ } \\
4 \mathrm{~km}\end{array}$ & $\begin{array}{r}\mathrm{CA} \\
1 \mathrm{~km}\end{array}$ & $\begin{array}{r}\mathrm{CA} \\
4 \mathrm{~km}\end{array}$ & $\begin{array}{r}\mathrm{AZ} \\
1 \mathrm{~km}\end{array}$ & $\begin{array}{r}\text { AZ } \\
4 \mathrm{~km}\end{array}$ \\
\hline Mean Bias (ppb) & -1.9 & -3.4 & 0.6 & -0.4 & -2.0 & -4.0 & -4.8 & -4.7 \\
\hline Normalized Mean Bias (NMB) & -7.9 & -13.5 & 2.5 & -1.7 & -8.6 & -16.3 & -18.5 & -18.4 \\
\hline Normalized Mean Error (\%) & 16.3 & 25.0 & 15.4 & 16.8 & 24.2 & 34.1 & 24.1 & 25.6 \\
\hline Mean Normalized Bias (\%) & -6.7 & -10.7 & 3.2 & -1.2 & -3.5 & -9.7 & -16.4 & -18.5 \\
\hline Mean Normalized Gross Error (\%) & 16.7 & 24.9 & 15.9 & 17.3 & 23.8 & 34.0 & 24.5 & 26.2 \\
\hline Correlation coefficient & 0.75 & 0.54 & 0.76 & 0.65 & 0.74 & 0.4 & 0.75 & 0.61 \\
\hline Root Mean Square Error (ppb) & 16.1 & 19.9 & 15.7 & 15.5 & 22.9 & 30.1 & 15.8 & 17.2 \\
\hline
\end{tabular}

area (Fast et al., 2000; Lee and Fernando, 2013), which can partly explain why the modeled $\left[\mathrm{O}_{3}\right]$ matched the observations, even though the modeled $\left[\mathrm{NO}_{x}\right]$ and $[\mathrm{CO}]$ are highly overestimated in the May case.

Table 1 presents the statistics of comparisons of surface ozone concentrations between the model and observations in Southern California (total 46 sites) and greater Phoenix area (total 24 sites), respectively. These statistics are widely used in evaluating model performance (Simon et al., 2012). Our statistics are comparable with those from previous studies in the two regions. For example, in Southern California, the mean biases, RSME and correlation coefficients shown in Table 1 are comparable with those from Huang et al. (2013, their Table 3) and Chen et al. (2013, their Tables 2 and 3). Furthermore, the mean normalized bias and mean normalized gross error are comparable with those from Taha (2008, in his Table 2). In greater Phoenix, these statistics are generally comparable with those from Lee et al. (2007), and Li et al. (2014).

To examine the effects of model resolution on surface ozone concentrations, we conducted two additional model runs. These two additional runs were set up and configured exactly the same as the $1.33 \mathrm{~km}$ runs; but, with just running WRF-Chem with Domains 1, 2, and 3, which means the highest resolution of model output is $4 \mathrm{~km}$. The model performance at $4 \mathrm{~km}$ resolution was also validated against ozone observations and summarized in Table 1. As shown in Table 1 , the model performed much better for the correlation coefficients, normalized mean gross errors, mean normalized bias, and normalized mean error at $1.33 \mathrm{~km}$ than those at $4 \mathrm{~km}$. For the mean bias and normalized mean bias, the model performed better in Southern California at $1.33 \mathrm{~km}$ than those at $4 \mathrm{~km}$, with similar performance in greater Phoenix. Therefore, we conclude that WRF-Chem in its present configuration performed better at $1.33 \mathrm{~km}$ resolution than that at $4 \mathrm{~km}$ resolution, based on the two events and on the 2005 NEI. Our results are consistent with previous studies (e.g., Taha, 2008; Tie et al., 2010). In the following analysis and discussion, we mainly focus on the model output at $1.33 \mathrm{~km}$ resolution.
The evaluation shown in Figs. 2-3, S3, and the statistical analysis presented in Table 1 demonstrate that the WRFChem model, in its current configuration and set up, produces simulated ozone concentrations comparable to the observations.

\subsection{Contribution of local and remote emissions to Phoenix $\left[\mathrm{O}_{3}\right]$}

Next, we investigate impacts of anthropogenic emissions in southern California (SoCal) and Arizona (AZ) on Phoenix $\left[\mathrm{O}_{3}\right]$. To achieve this goal, we have conducted additional WRF-Chem simulations for the selected cases with the same model setup as presented and evaluated in Sects. 2.1 and 3.1, and refer to these experiments as "CTRL", but with (1) exclusion of SoCal emissions (indicated as the dashed-red-line box in Fig. 1b) and called "noCA"; (2) exclusion of AZ emissions (indicated as the dashed-black-line box in Fig. 1b) and called "noAZ"; and (3) exclusion of all anthropogenic emissions in Domain 4, and called Biogenic emissions and Lateral Boundary inflow (BILB).

Figure 4 shows the hourly $\left[\mathrm{O}_{3}\right]$ comparison for observations (Obs), CTRL, noCA, noAZ, and BILB simulations at selected observation sites in the Phoenix area on 1114 May 2012, (Fig. 4a-f) and 16-19 July 2005 (Fig. 4g-1). Figure 4 indicates that hourly $\left[\mathrm{O}_{3}\right]$ from the CTRL run match the observations very well in western downtown (ID0019, ID2001), central downtown (ID3003, ID9997), and east and north suburban areas (ID9508, ID9702). AZ emissions are the principal contribution to ozone production over Phoenix during daytime (compare the change in simulated $\left[\mathrm{O}_{3}\right]$ as demonstrated by the red contour [CTRL] and dashed-blue contour [noAZ]), with a maximum magnitude of up to 40 60 ppbv hourly (compare differences between CTRL and noAZ). The contribution of SoCal emissions to Phoenix $\left[\mathrm{O}_{3}\right]$ ranges between $10-40 \mathrm{ppbv}$ during daytime (compare the change in simulated $\left[\mathrm{O}_{3}\right]$ as demonstrated by the red contour [CTRL] and green contour [noCA]). Based on the BILB run (gray contour), the contribution of biogenic emissions (including larger-scale lateral input) to Phoenix $\left[\mathrm{O}_{3}\right]$ varies 


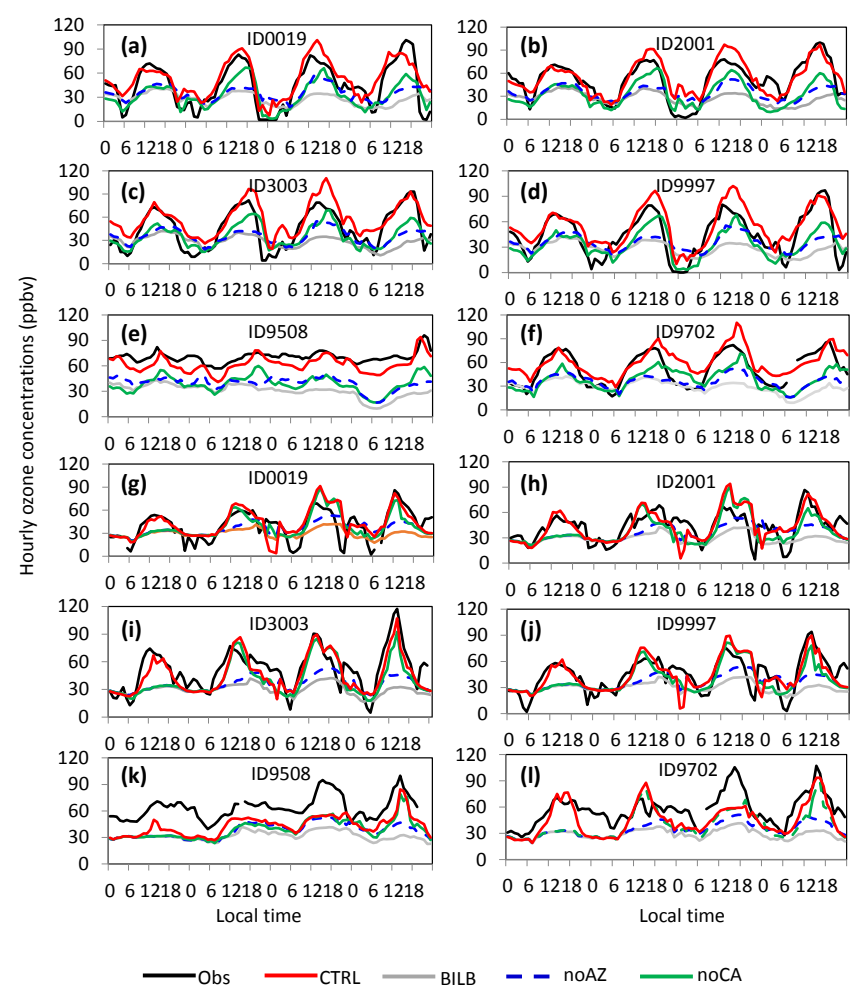

Figure 4. Relative contributions of different emission scenarios to $\left[\mathrm{O}_{3}\right]$ at observation sites in Phoenix metropolitan area and surrounding rural areas. The dates are 11-14 May 2012 (a-f) and 1619 July 2005 (g-l). Idxxxx corresponds to the EPA AIRS site number in Maricopa County, Arizona. Black line indicates the $\left[\mathrm{O}_{3}\right]$ observation. Red line represents the simulated $\left[\mathrm{O}_{3}\right]$ for the CTRL run. Blue line shows the $\left[\mathrm{O}_{3}\right]$ for the noAZ run. Green line displays the $\left[\mathrm{O}_{3}\right]$ for the noCA run. Gray line is the $\left[\mathrm{O}_{3}\right]$ for the BILB run.

between 25-35 ppbv, indicating a baseline target for emission reduction strategies. Following Huang et al. (2013), the contribution of SoCal to $\left[\mathrm{O}_{3}\right]$ in the Phoenix area is the difference between the CTRL and noCA experiments. The relative contributions from SoCal, AZ, and BILB emissions to hourly $\left[\mathrm{O}_{3}\right]$ at observation sites for 19 July 2005 and 14 May 2012 are shown in Figs. S4 and S5.

Figures 4 and S4 and S5 indicate the relative contribution of SoCal and $\mathrm{AZ}$ emissions to $\left[\mathrm{O}_{3}\right]$ vary with time. Physical and chemical processes at each stage can explain this variation. During nighttime, noCA $\left[\mathrm{O}_{3}\right]$ are less than that of the noAZ run. This is because there is no ozone consumption (or titration) in the noAZ run while transported ozone can still make its contribution. After sunrise, solar radiation heats the ground surface, increasing the planetary boundary layer (PBL) height. Ozone accumulated within a residual layer from previous day(s) is entrained into the PBL, increasing ground-level $\left[\mathrm{O}_{3}\right]$. This process continues until the PBL height reaches its peak. Simultaneously, ozone production starts with its precursor emissions in the presence of sunlight, a rate that increases with increasing sunlight intensity
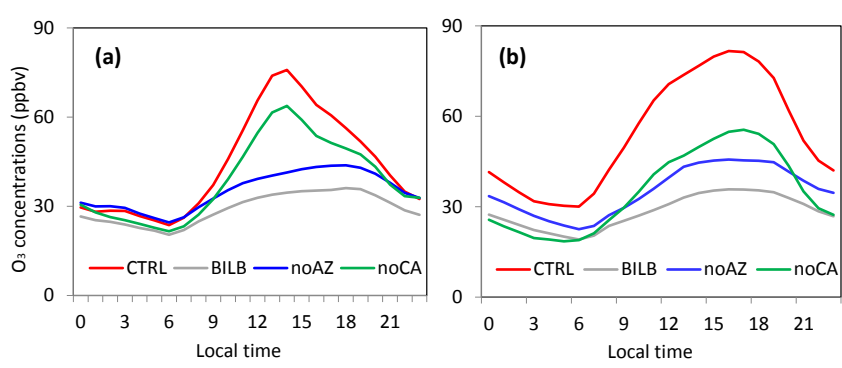

Figure 5. Simulated diurnal variations of $\left[\mathrm{O}_{3}\right]$ at Phoenix urban setting for different emission scenarios: (a) average from 1619 July 2005, and (b) average from 11-14 May 2012.

and surpasses the transport rate of $\left[\mathrm{O}_{3}\right]$ by mid to late afternoon. Furthermore, the figures indicate that the peak time of $\left[\mathrm{O}_{3}\right]$ differs between the CTRL run and the noAZ run at some locations for some days. These differences of $\left[\mathrm{O}_{3}\right]$ peak time indicate the importance of ozone transport. Figure 5 displays the mean diurnal variation of $\left[\mathrm{O}_{3}\right]$ for the different emission scenarios for the two cases. The data are averaged over all urban grid cells (i.e., not solely over the station sites presented in Fig. 4) in Phoenix for 11-14 May 2012, and 1619 July 2005, respectively. The relative contribution of emissions to Phoenix $\left[\mathrm{O}_{3}\right]$ are clear and the diurnal features are similar to those shown in Figs. 4, and S4 and S5, emphasizing the crucial roles of both local and remote emissions.

The daily maximum $8 \mathrm{~h}$ average (DMA8) $\left[\mathrm{O}_{3}\right]$ from CTRL and the relative contributions to DMA8 $\left[\mathrm{O}_{3}\right]$ from different emission scenarios (BILB, SoCal, and AZ) are assessed at observation sites and for all urban grid cells within Phoenix (Fig. 6). The model reproduces observations very well with a slight underestimation on 19 July 2005, but with an overestimation on 13 May 2012. The contribution of SoCal to DMA8 $\left[\mathrm{O}_{3}\right]$ in the Phoenix area ranges between 20-30 ppbv for the May case and 5-20 ppbv for the July case. Relative to the CTRL run, the percentage contributions of 26-36\% for the May case and 7-38\% for the July event emphasize the significant effect of Southern California emissions on Phoenix metropolitan area air quality. For the two episode days, the contributions are $28 \mathrm{ppb}(36 \%)$ for 14 May 2012, and 11 ppb (16\%) for 19 July 2012. The relative contributions of AZ local emissions to greater Phoenix observation sites are also shown in Fig. 6. Overall, the relative contributions of AZ local emissions to Phoenix $\left[\mathrm{O}_{3}\right]$ are more than that of SoCal emissions.

The means of DMA8 $\left[\mathrm{O}_{3}\right]$ throughout the Phoenix urban area (about 1100 grid cells) arising from the different emission scenarios are shown in Fig. 6b and d, and indicate similar values to those at observation sites (Fig. 6a, c). The contribution of SoCal emission to DMA8 $\left[\mathrm{O}_{3}\right]$ for the Phoenix metropolitan area ranges between $20-32$ ppbv for the 11-14 May 2012, case, and from 6-22 ppbv for the 1619 July 2005, case. The percentages, relative to CTRL, are from 27 to $37 \%$ for $11-14$ May and from 9 to $40 \%$ for 

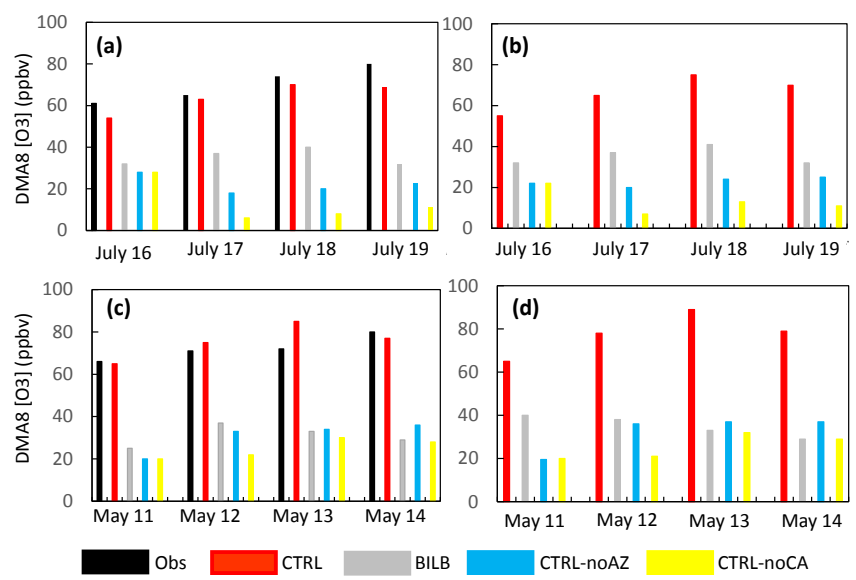

Figure 6. Mean DMA8 $\left[\mathrm{O}_{3}\right]$ in Phoenix metropolitan area from observation (Obs), simulation from CTRL runs (CTRL), BILB runs (BILB), and the relative contributions of different emission sources. CTRL-noAZ represents the modeled DMA8 $\left[\mathrm{O}_{3}\right]$ differences between CTRL run and noAZ run. CTRL-noCA displays the modeled DMA8 $\left[\mathrm{O}_{3}\right]$ differences between CTRL run and noCA run. Observation sites show in Fig. 1b. (a) DMA8 $\left[\mathrm{O}_{3}\right]$ at observation sites for 16-19 July 2005, (b) the same as (a) but for that averaged from Phoenix urban grid cells. (c) and (d), the same as (a) and (b) but for the case of 11-14 May 2012.

16-19 July. Considering only the 2 days with the maximum ozone concentrations, the contributions are $29 \mathrm{ppb}(37 \%)$ and $11 \mathrm{ppb}(16 \%)$ for 14 May and 19 July, respectively.

Note that in Fig. 6, the differences of CTRL minus BILB is not equal the sum of the differences of CTRL minus noCA plus that of CTRL-noAZ. The reason could be the nonlinear processes among emissions, physical, and/or chemical mechanisms (Kwok et al., 2015) and the uncertainties of the entire system: both the emissions and the models themselves.

Figure 6 demonstrates the following results: (1) the impact of $\mathrm{AZ}$ emissions on DMA8 $\left[\mathrm{O}_{3}\right]$ in the Phoenix area is greater than that of the SoCal's; (2) even so, SoCal emissions considerably increase DMA8 $\left[\mathrm{O}_{3}\right]$ in the Phoenix area by up to $30 \mathrm{ppbv}$, though this is day and case dependent; (3) the DMA8 $\left[\mathrm{O}_{3}\right]$ from the BILB experiment are in excess of $30 \mathrm{ppbv}$, including the contributions of biogenic emissions and lateral boundary transport. Based on the diurnal variations shown in Figs. 4 and 5, and Figs. $\mathrm{S} 4$ and $\mathrm{S} 5,\left[\mathrm{O}_{3}\right]$ due to biogenic emissions and lateral boundary inflow could be 10 $17 \mathrm{ppbv}$. In other words, the contribution of BILB to Phoenix DMA8 $\left[\mathrm{O}_{3}\right]$ cannot be ignored despite the region's aridity and lack of dense forests. Note that all of these results are based on the US EPA 2005 national emissions inventories.

Figure 7 depicts the spatial distributions of DMA8 $\left[\mathrm{O}_{3}\right]$ for different emission scenarios on 19 July 2005. The CTRL run indicates that higher $\left[\mathrm{O}_{3}\right]$ occur in the northeastern urban perimeter, which is consistent with previous studies (e.g. Lee and Fernando, 2013). The effects of SoCal emissions and AZ local emissions on DMA8 $\left[\mathrm{O}_{3}\right]$ are location-dependent. The
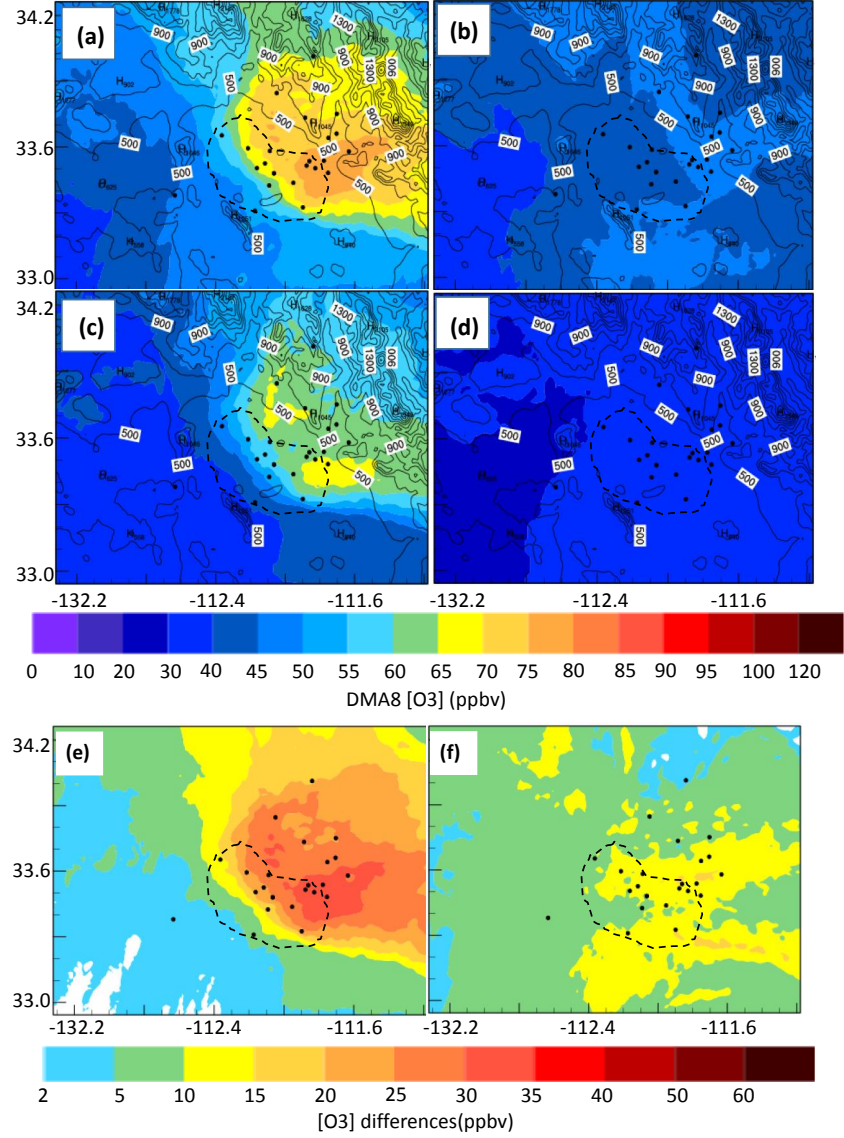

Figure 7. DMA8 $\left[\mathrm{O}_{3}\right]$ spatial distributions in Greater Phoenix and surrounding areas on 19 July 2005: (a) CTRL, (b) noAZ, (c) noCA, (d) BILB, (e) CTRL-noAZ, and (f) CTRL-noCA. Contours represent terrain elevations. Dots show $\mathrm{O}_{3}$ observation sites. Circle indicates the approximate location of Phoenix urban area.

case of 14 May 2012, is also examined (see Fig. S6) and a similar distribution as in Fig. 7 is found, but it differs in magnitude.

In summary, our results demonstrate that removing SoCal emissions would facilitate attainment of $\left[\mathrm{O}_{3}\right]$ in Phoenix on some days, but not on others. In other words, SoCal emissions are an important, if uneven, contributor to the DMA8 $\left[\mathrm{O}_{3}\right]$ exceedances for Phoenix. In addition, the effects of SoCal emissions on Phoenix DMA8 $\left[\mathrm{O}_{3}\right]$ are locationdependent (see Figs. 7 and S6). From a pollution control point of view, our results indicate that reducing the emissions emitted in Phoenix is the key to attain federal standards. With typical synoptic wind fields, emissions from Southern California affect ground-level $\left[\mathrm{O}_{3}\right]$ in the Phoenix metropolitan area significantly. Therefore, the results indicate that Phoenix would benefit from regional, in addition to local, emission controls to reach NAAQS attainment status. 


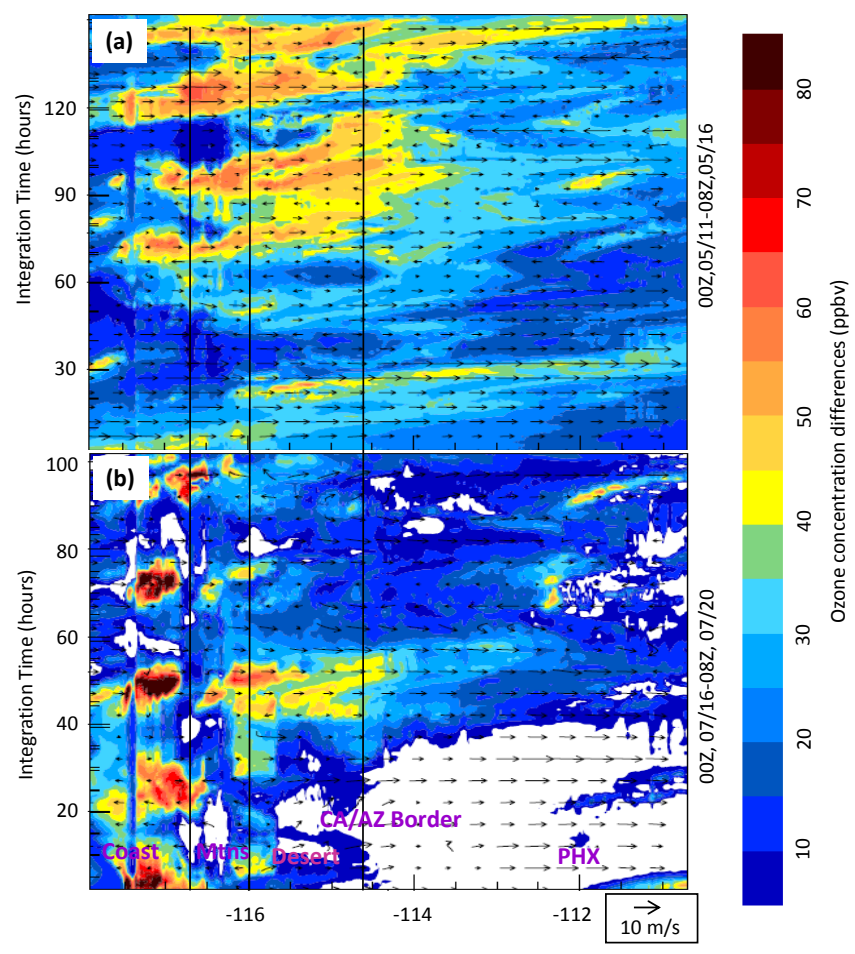

Figure 8. Hovmoller diagram of $\left[\mathrm{O}_{3}\right]$ differences (CTRL minus noCA) at 13th vertical model layer (about $1100 \mathrm{~m}$ a.g.1.) along the cross-section B'B shown in Fig. 1b for May case (a) and July case (b). Approximate locations of Phoenix (PHX), desert, mountains (Mnts), and coast are also labeled in (b). The integrating is counted from 00:00 UTC, 10 May 2012, and 00:00 UTC, 15 July 2005, respectively.

\subsection{Southern California to Arizona $\left[\mathrm{O}_{3}\right]$ transport}

Through analysis of $\left[\mathrm{O}_{3}\right]$ variations with the various emission scenarios, $10-30 \%$ of $\left[\mathrm{O}_{3}\right]$ in the Phoenix area can be attributed to SoCal emissions for the cases presented here. In this section we will examine pathways characterizing how pollutants in the coastal air basins of Southern California are transported into Arizona and affect air quality in the Phoenix area based on $1.33 \mathrm{~km}$ resolution model output. The corresponding analyses of the results from the $4 \mathrm{~km}$ resolution output can be found in the Supplement.

Figure 8 a shows a Hovmoller diagram of $\left[\mathrm{O}_{3}\right]$ differences (CTRL minus noCA) and the wind vector field (from CTRL run) for the May case at the model's 13th vertical level (about $1100 \mathrm{~m}$ above ground-level, or a.g.l.) of WRF-Chem along the cross-section B'B (indicated in Fig. 1b). The Hovmoller diagram is a suitable technique to identify transport and propagating phenomena in a given field (i.e. Hovmoller, 1949). In Fig. 8a, the $y$ axis is the model integration time (hours) and the $x$ axis is the location (longitude) along the B'B transect. The approximate locations of Phoenix (PHX), desert, mountains (Mnts) and coast are also labeled in this figure. Since both CTRL and noCA experiments include the same emissions except over California, the difference in ozone between these experiments offsets the chemical ozone production east of California and west of Phoenix. Thus, the residual ozone perturbation field in these regions is dominated by transport. The pattern of this field exhibits tilted ozone bands with phase lines that have consistent positive slopes (Fig. 8a), indicating that a perturbation of ozone in California will eventually reach Arizona. This demonstrates that the residual ozone field shown in Fig. 8a is caused by transport from California to Arizona. The Hovmoller diagram of $\left[\mathrm{O}_{3}\right]$ differences for the July case also exhibits patterns of residual ozone with positive slopes indicating transport (Fig. 8b). These slopes are, however, less pronounced than the May case.

The data within each model vertical layer are examined. It is found that peak transport occurs in different model layers depending on the event. For the July event, there is ozone transport from the 5th model layer (about $150 \mathrm{~m}$ a.g.l.) to the 13th model layer (1100 ma.g.l.). For the May event, ozone transport occurs from the 5th to 17 th $(2000 \mathrm{~m}$ a.g.l.) model layers. The Hovmoller diagrams for $\mathrm{NO}_{x}$ and VOCs indicate that most air masses of $\mathrm{NO}_{x}$ and VOCs are horizontally confined near emission source areas and are vertically restricted to below about $1500 \mathrm{~m}$ a.g.l. (figure not shown), compared to the magnitude presented in Fig. 8 .

We next examine how pollutants from Southern California are transported into south-central Arizona and discuss the physical-chemical mechanisms responsible. Analysis of anthropogenic emission distributions indicates that emissions mainly originate from coastal areas in Southern California (also see their Fig. 1 in Chen et al. , 2013 for emission distribution). Therefore, we first explain how the pollutants cross the coastal mountains and reach the inland desert regions in Southern California.

As discussed in Sect. 1, wind fields are paramount in pollutant transport (Lee et al., 2007). Figure 9 displays the daytime averaged (20:00 to 02:00 UTC) wind vector field at $40 \mathrm{~m}$ a.g.l. in the Southern California coastal area of 16-19 July 2005 (for $4 \mathrm{~km}$ resolution plots, see Fig. S7). The wind patterns exhibit a combination of on-shore ocean breezes and mountain-induced upslope winds, similar to features reported by Lu and Turco (1996) and Lu et al. (1997). The wind field distribution shown in Fig. 9 propels pollutants emitted in coastal areas towards the coastal mountains. The polluted air masses can be lofted up to 3-4 km a.g.l. over the mountains through the Mountain Chimney Effect (MCE, Lu and Turco, 1996). The pollutants above mountain-top height might either be transported into the free atmosphere over the coast (Lu and Turco, 1996) and/or be transported towards the inland desert and affect the air quality in the desert of Southern California (Huang et al., 2013; VanCuren, 2015) and of nearby mountain states (Langford et al., 2010; Huang et al., 2013).

The entire transport path, from the Southern California coast to south-central Arizona, and the associated ozone ver- 


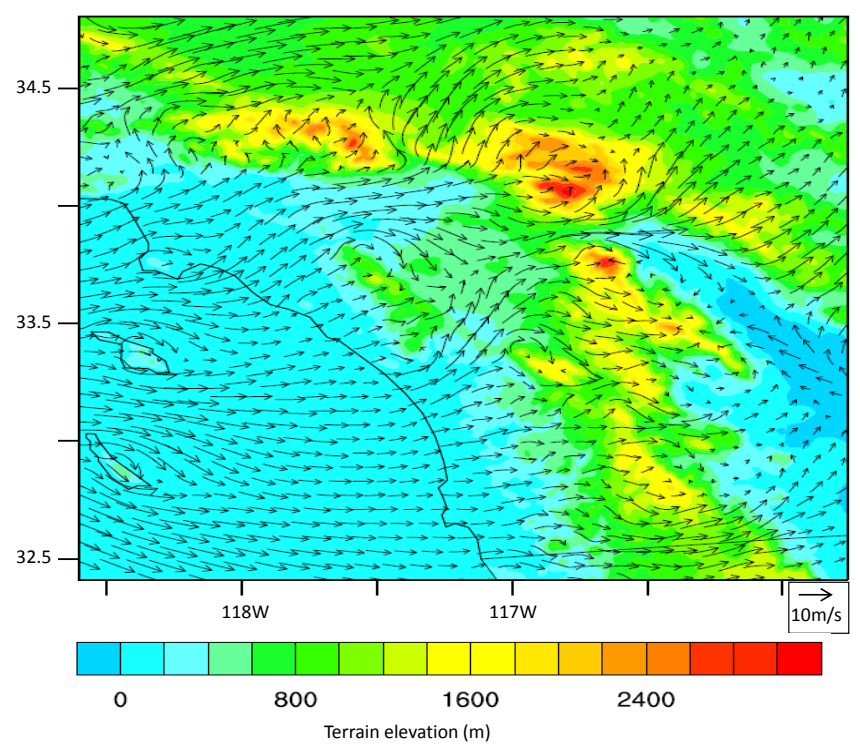

Figure 9. Wind vector field at $40 \mathrm{~m}$ above surface layer in southern California coastal area. Data are averaged from 20:00 to 02:00 UTC, 16-20 July 2005.

tical distributions along cross-sections A'A, B'B, D'D and E'E, is described here in this subsection. First, vertical distributions of $\left[\mathrm{O}_{3}\right]$ along cross-sections A'A and B'B are checked from 21:00 to 24:00 UTC each day and Fig. 10 is an example of vertical distributions of $\left[\mathrm{O}_{3}\right]$ along cross-section A'A and B'B at 22:00 UTC on 17 July 2005 (for $4 \mathrm{~km}$ resolution plots, see Fig. S8). Results presented in Fig. 10 are similar to those reported by Lu and Turco (1996, in their Figs. 4 and 6) from modeling and Langford et al. (2010; in their Fig. 3) from observations, indicating that WRF-Chem adequately simulates the Mountain Chimney Effect (MCE). Note the distribution of potential temperature contours in Fig. 10, illustrating that ozone-laden air masses above mountain peak height may be directly transported into the desert PBL under appropriate flow at these levels. This pattern differs from that of transport back to the free atmosphere over coastal basins (note the tongue of high $\left[\mathrm{O}_{3}\right]$ to the west of the peak in Fig. 10a). This is because of the particularly high PBL height (in excess of 3-4 km a.g.1.) in the desert during daytime due to strong solar radiation. At nighttime, ozone air masses subsequently subside into the residual layers and/or stable PBL in the desert, and are continuously advected by westerly winds (part of the near-surface ozone will be consumed by titration from $\mathrm{NO}_{x}$ and by deposition during nighttime). Importantly, Fig. 9 indicates the presence of strong winds from the coast flowing through the mountain passes. For example, there are southerly winds flowing along the $\mathrm{Ca}-$ jon Pass (see location in Fig. 1b) and strong westerly winds flowing along the San Gorgonio Pass (see location Fig. 1b), which are realistic and consistent with the immense fields of wind turbines there. With the wind pattern shown in Fig. 9,

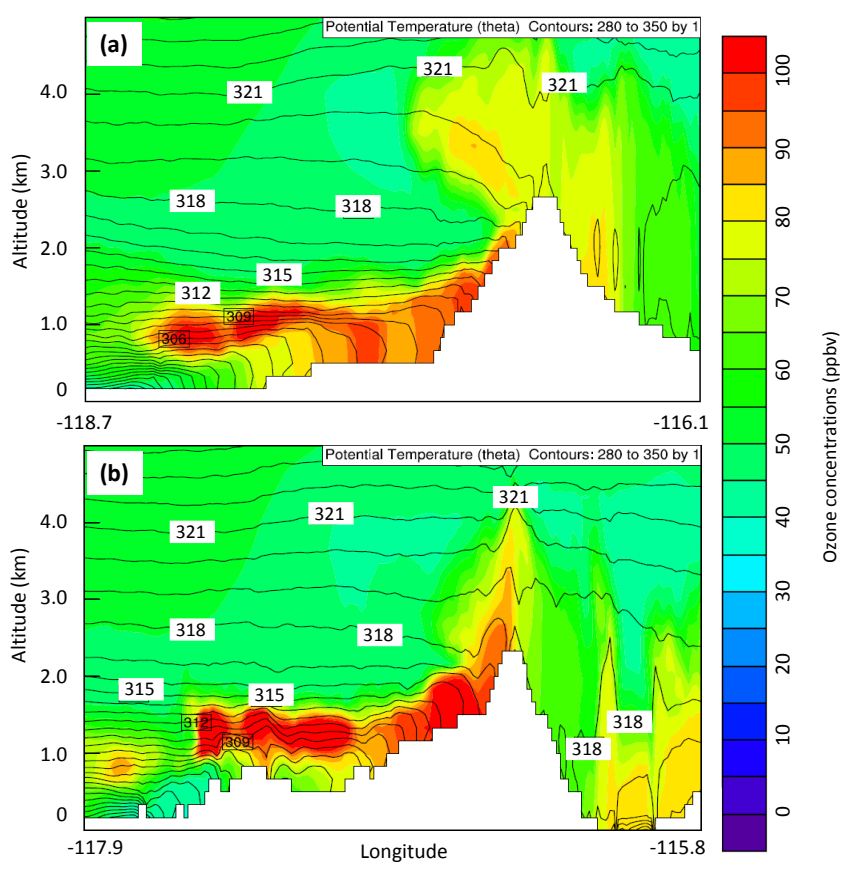

Figure 10. Vertical distributions of ozone along cross-section A'A (a) and B'B (b) shown in Fig. 1b at 22:00 UTC of 17 July 2005. The contours are potential temperature starting at $280 \mathrm{~K}$ with $1 \mathrm{~K}$ interval.

ozone in low air layers can be directly transported into the southern Mojave Desert Air Basin (SMDAB, see Fig. 1b) from the greater Los Angeles Air Basin (GLAAB) through the Cajon Pass. Ozone can also be transported eastward to the Salton Sea Air Basin (SSAB) from the GLAAB through the San Gorgonio Pass and from the San Diego Air Basin (SDAB) through other passes (see Fig. 9 for the locations and wind vectors).

To demonstrate the model performance in simulating $\left[\mathrm{O}_{3}\right]$ in the passes, Fig. 11 presents the hourly comparison of $\left[\mathrm{O}_{3}\right]$ between observations and simulations (CTRL) at Crestline, near the Cajon Pass, and Banning Airport, near the San Gorgonio Pass. Figure 11 shows that the simulations and the observations are comparable from 17 to 19 July 2005. In Fig. 11, model simulations with $12 \mathrm{~km}$ resolution are also plotted to characterize resolution-dependency. It is clear that with higher resolution, simulated results are improved above those of coarser resolution, a feature likely due to more accurate ozone transport through the passes.

Figure 12 shows the horizontal distribution of the integrated fluxes of ozone differences $\left(\int\left(\left[\mathrm{O}_{3}\right]_{\mathrm{CTRL}}-\right.\right.$ $\left.\left.\left[\mathrm{O}_{3}\right]_{\text {noCA }}\right) \boldsymbol{V}_{\mathrm{CTRL}} \mathrm{d} z\right)$ from the surface to $1400 \mathrm{~m}$ a.g.l. averaged from (a) 18:00 to 02:00 UTC and (b) 03:00 to 17:00 UTC, 16-20 July 2005 (data from the other case 1115 May 2012 are similar and for $4 \mathrm{~km}$ resolution plot, see Fig. S9). Figure 12 emphasizes two key aspects of this transport: 

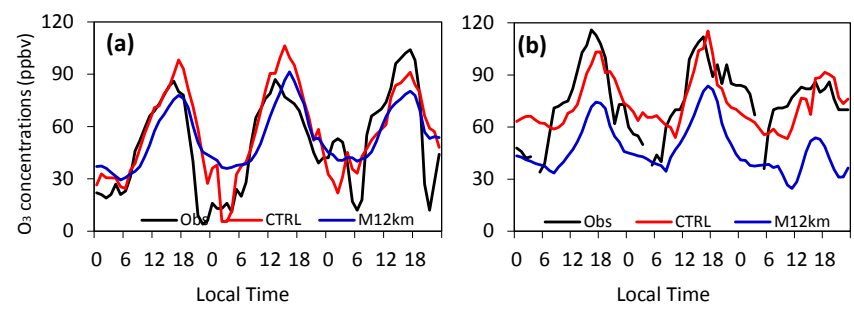

Figure 11. Ground-level ozone concentration comparisons between observations and simulations at (a) Banning Airport (ID0650012, $33.92077^{\circ},-116.85841^{\circ}$ ) located in the San Gorgonio Pass and (b) Crestline (ID060710005, 34.24313 ${ }^{\circ},-117.2723^{\circ}$ ) near the Cajon Pass from 17-19 July 2005. Obs indicates the observation. CTRL represents the simulations from CTRL run and M12km is the model simulations at $12 \mathrm{~km}$ resolution.

1. There were stronger fluxes in the mountain passes, especially in the San Gorgonio Pass, than any other location, indicating the important contributions of mountain passes to ozone transport. Most recently, VanCuren (2015), based on analysis of ozone observations, also suggests the importance of ozone transported into the MDAB through the passes and has confirmed our model results.

2. Ozone fluxes are present, originating from the coasts and mountains in Southern California, extending southeastward along the SSAB and the SMDAB (Fig. 12b), crossing the California-Arizona border near the southern Colorado River, then moving northeastward (Fig. 12b) along the Lower Gila river basin, and finally reaching the Phoenix area.

The vertical distribution of pollutants is also evaluated along cross-section D'D in the Salton Sea Valley and crosssection E'E in the Gila River Valley (locations are labeled in Fig. 1b). Presenting vertical distributions of VOC, $\mathrm{NO}_{x}$ and $\mathrm{O}_{3}$ along D'D on 18 July from CTRL, Fig. 13 depicts the transport of the pollutants from late afternoon to midnight, as indicated by the location of high-concentration fronts (for the corresponding $4 \mathrm{~km}$ resolution plots, see Fig. S10). The $\mathrm{NO}_{x}$ masses are vertically confined to below $1 \mathrm{~km}$ above sea level (a.s.1.) with concentrations of 5-15 ppbv. VOC plumes are confined below $2 \mathrm{~km}$ a.s.l. with concentrations of 10 $20 \mathrm{ppbv}$. We also evaluated the vertical distribution of VOC from the BILB emissions experiment: the vertical distribution is similar to the VOC shown in Fig. 13, but the concentrations are about $10 \mathrm{ppbv}$ (figure not shown). In other words, there are about $10 \mathrm{ppbv}$ of VOC that are transported from coastal anthropogenic emissions to this region. Similar to $\mathrm{NO}_{x}$ concentrations, the highest concentrations of VOC are near the ground surface.

Ozone vertical distributions reach up to $2-3 \mathrm{~km}$ a.s.l. with concentrations as high as $90 \mathrm{ppbv}$. The high $\left[\mathrm{O}_{3}\right]$ is centered $1-2 \mathrm{~km}$ a.s.l. during nighttime while $\left[\mathrm{O}_{3}\right]$ is low near ground-

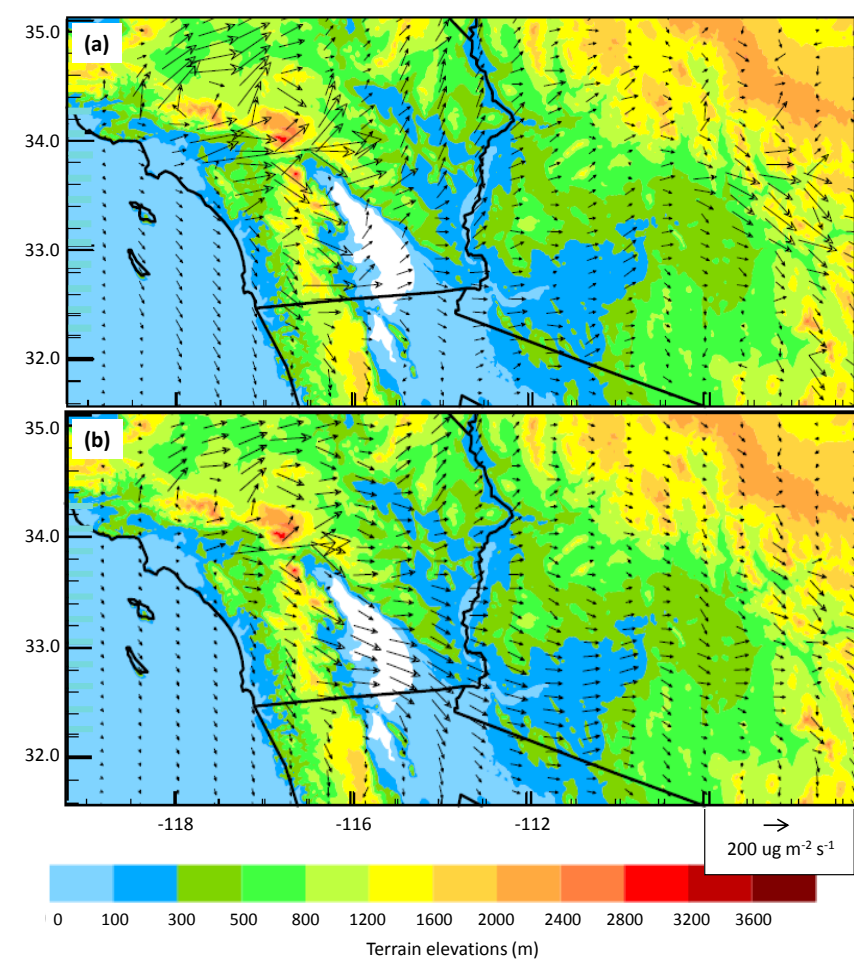

Figure 12. Integrated fluxes of ozone differences (CTRL-noCA) from surface to $1400 \mathrm{~m}$ above ground-level: (a) average from 18:00 to $02: 00 \mathrm{UTC}, 16$ to 20 July 2005, and (b) average from 03:00 to 17:00 UTC, 16 to 20 July 2005.

level due to the chemical titration by $\mathrm{NO}_{x}$ and dry deposition (Fig. 13). In other words, among the three pollutants, ozone is most "long-lived" and $\mathrm{NO}_{x}$ has the shortest span, which is consistent with their atmospheric chemistry and previous results (e.g., Lee and Fernando, 2013).

The diurnal variation of a pollutant is, in part, a consequence of diurnal variation of flow (the other principal influence is the diurnal variation of the emissions themselves). During daytime, southeasterly winds (valley winds) at lower layers in the northern Salton Sea basin hinder the pollutants from being transported southeastward along the Salton Sea Basin (See Figs. 12a and 9). Therefore, a portion of the pollutants, transported from the GLAAB through the San Gorgonio Pass, accumulate over the northern Salton Sea basin (as shown at 01:00 UTC in Fig. 13), while a different portion of the pollutants crossed the Little San Bernardino Mountains and reached the SMDAB due to upslope flow (see Figs. 12a and 9). During nighttime, basin-scale mountain downslope winds transport the pollutants southeastward along the SSAB basin (Figs. 12b and 13).

Figure 14 is similar to Fig. 13 but presents results for the cross-section E'E in the Gila River basin in Arizona (location shown in Fig. 1b) on 18 July (corresponding 4 km resolution plots, see Fig. S11). During this time period, although concentrations of pollutants continued to decrease along this 

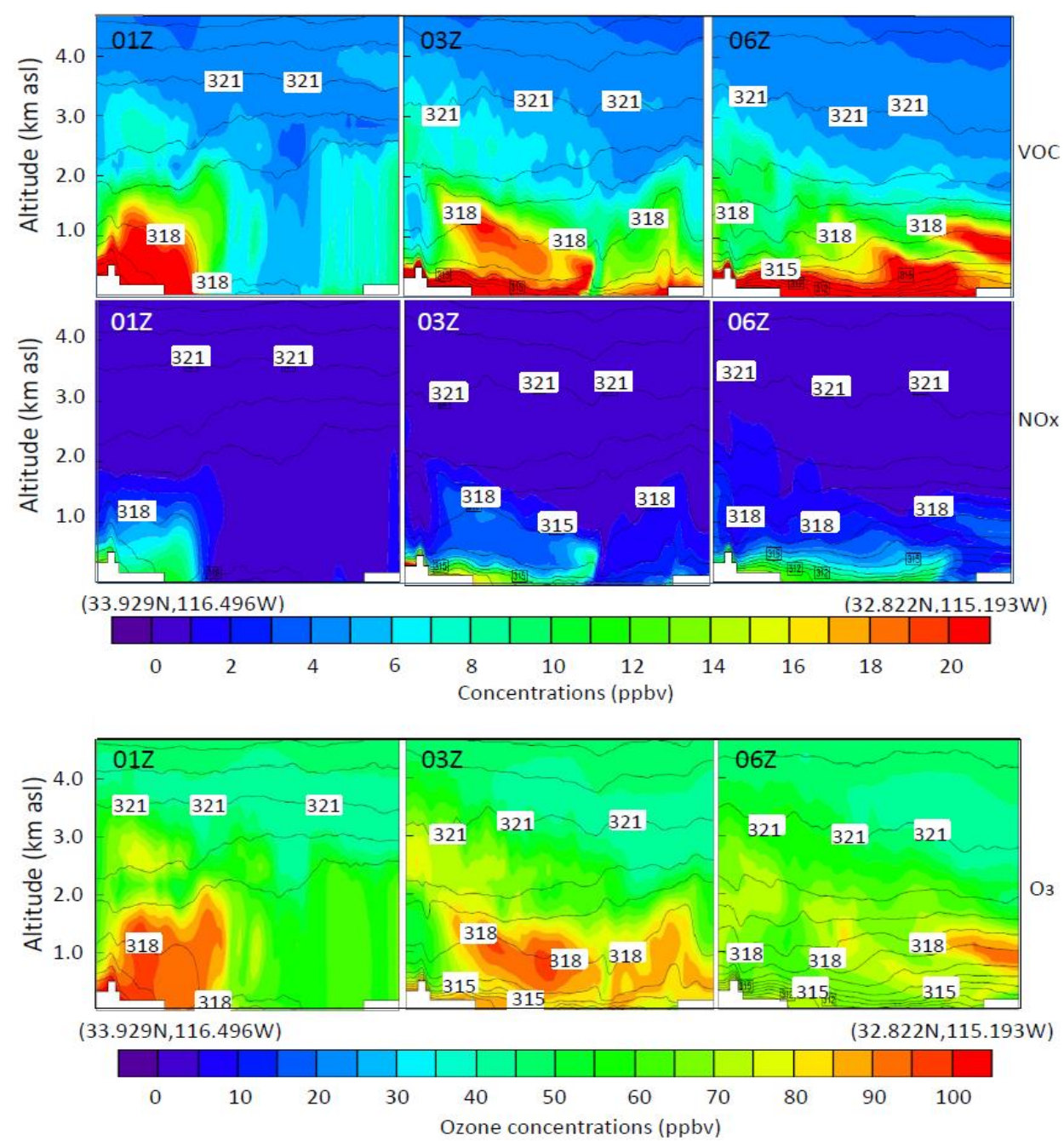

Figure 13. The vertical distribution of VOC (top), $\mathrm{NO}_{x}$ (middle), and $\mathrm{O}_{3}$ (bottom) along the cross-section $\mathrm{D}$ 'D (shown in Fig. 1b) in the Salton Sea Basin at 01:00, 03:00, and 06:00 UTC, 18 July 2005. Contours are potential temperature with $1 \mathrm{~K}$ interval.

transport pathway, the ozone transport phenomenon was still very clear along the Gila River basin due to the prevailing nighttime southwesterly winds (see Fig. 12). These southwesterly winds can result from either the low-level jet from the northern Gulf of California during monsoon season (midJuly to mid-September, Adams and Comrie, 1997) or by the inertia from a remnant of daytime westerly winds during premonsoon season (from May to mid-July, Lee and Fernando, 2013). At about 18:00 UTC, the ozone in the residual layer mixes with PBL ozone generated by local photochemical reactions, and finally affects the ground-level concentrations in Phoenix and its surrounding rural areas.

The results presented in this section are mainly based on model simulations. In past decades, there were a few field experiments conducted to measure the vertical distributions of meteorological fields and trace gases in southern California (e.g., the Southern California Air Quality Study in 1987; Lawson, 1990; the Southern California Ozone Study in 1997;
Croes and Fujita, 2003 and CALNEX-2010; www.esrl.noaa. gov/csd/calnex/) as well as in the Phoenix area (e.g., Phoenix Air Flow Experiment II in 1998; Fast et al., 2000; Nunnermacker et al., 2004). Some of the events during the experiments have been used to address ozone transport (e.g., Huang et al., 2013; Langford et al., 2010) from the Southern California coast. No aloft measurements could be found for May 2010 that would be of help in the present model performance evaluation. In addition, satellite-retrieved data may be used to demonstrate the vertical distributions and even distant transport (e.g., Huang et al., 2013), although these data are hampered by limitations such as coarse-resolution, accuracy, etc. (e.g., Bowman, 2013). To quantitatively examine the transport and vertical distribution from Southern California coasts to Phoenix, field observations, especially measurements aloft, along the inland California desert region and within western Arizona are needed. 

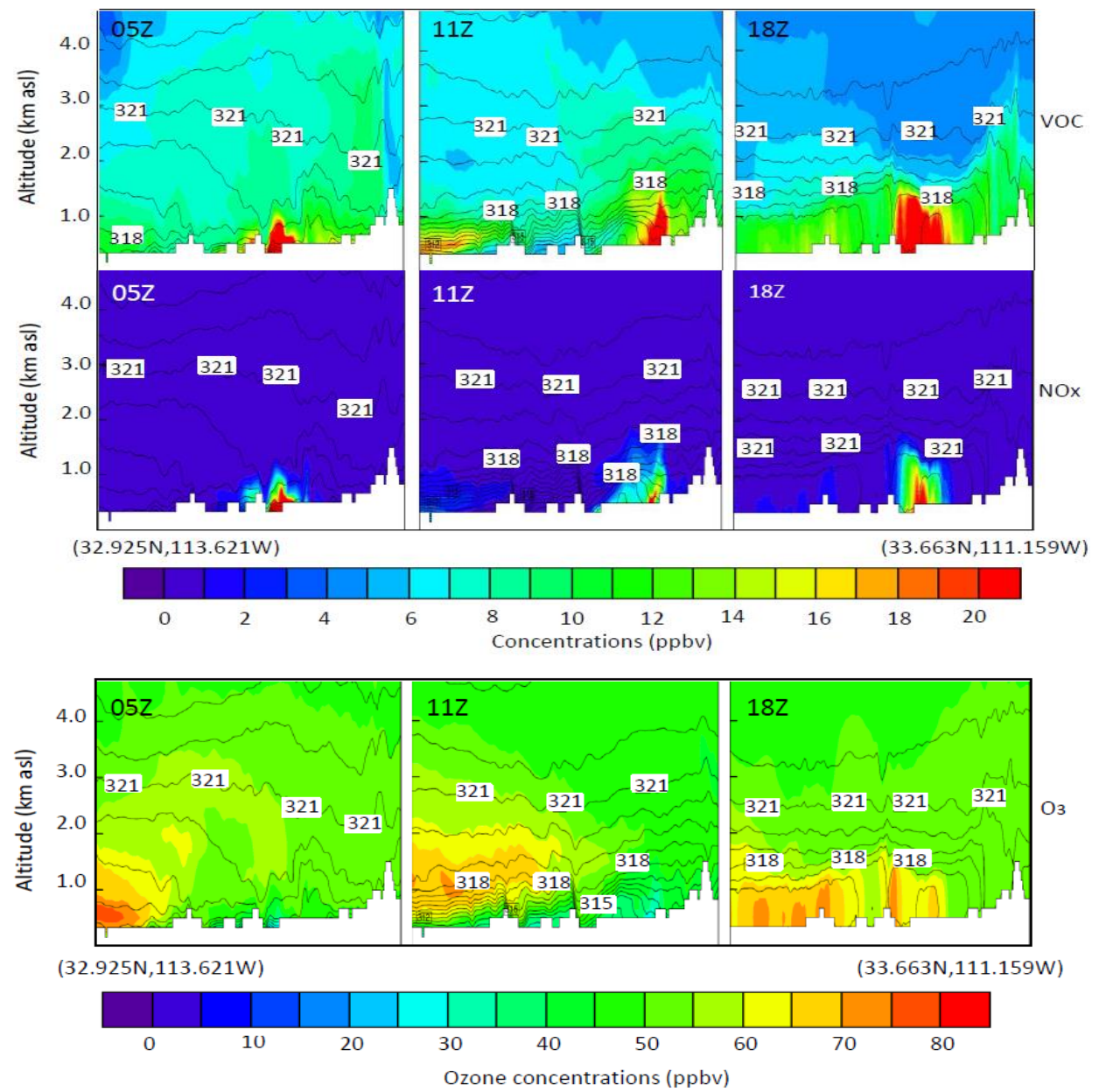

Figure 14. The vertical distribution of VOC (top), $\mathrm{NO}_{x}$ (middle), and $\mathrm{O}_{3}$ (bottom) along the cross-section $\mathrm{D}$ 'D (shown in Fig. 1b) in the Gila River Basin, Arizona at 05:00, 11:00, and 18:00 UTC, 18 July 2005. Contours are potential temperature with $1 \mathrm{~K}$ interval.

\section{Conclusions}

As with other cities, Phoenix's ozone concentrations on exceedance days can be attributed to both local precursor emissions and to the transport of ozone and its precursors from remote regions. In this study, WRF-Chem at high resolution ( $\sim 1.333 \mathrm{~km}$ grid spacing) is employed to investigate surface ozone distributions in Southern California and southcentral Arizona for two selected Phoenix episodes. Model simulations have been compared with surface observations of hourly ozone, $\mathrm{CO}, \mathrm{NO}_{X}$ and wind fields in Southern California and Arizona. The results indicate that the WRF-Chem configuration in this study can adequately simulate the spatial distribution, the magnitude, and the variability of the observations. The modeled ozone concentrations $\left(\left[\mathrm{O}_{3}\right]\right)$ are comparable with previous studies in the focus region.

Three sensitivity studies have been conducted to separate the contributions of Southern California anthropogenic emissions (SoCal), of the Arizona local anthropogenic emissions (AZ), and of biogenic emissions and lateral bound- ary input to Phoenix $\left[\mathrm{O}_{3}\right]$ on the exceedance days: (1) running WRF-Chem as CTRL but excluding SoCal emissions (noCA), (2) running WRF-Chem as the Control simulation but excluding AZ emissions (noAZ) and (3) running WRFChem as the Control simulation but excluding all anthropogenic emissions in domain 4 areas, leaving the Biogenic emissions and Lateral Boundary input (BILB). Our simulations indicate that $\mathrm{AZ}$ emissions play the key role in formation of the elevated $\left[\mathrm{O}_{3}\right]$ in Phoenix for the selected cases (see Figs. 4, 5, and 6). Based on the US EPA 2005 emissions inventories, SoCal emissions contribute to DMA8 $\left[\mathrm{O}_{3}\right]$ in the Phoenix area, and this impact varies between 5-30 ppbv at various observation sites and from 6-32 ppbv throughout the urban setting. In addition, our model simulations indicate the effects of SoCal emissions on DMA8 $\left[\mathrm{O}_{3}\right]$ in Phoenix are location and event dependent, but not negligible. The effects of BILB contributions to Phoenix DMA8 $\left[\mathrm{O}_{3}\right]$ are also significant in spite of the region's aridity. Our future research will distinguish biogenic and lateral boundary inflow contribution to this area through model simulations and observations. The 
model results are based on the 2005 US National Emissions Inventories (NEI, 2005). With more stringent emission control strategies in California, the effects of the pollutants transported from California could be reduced.

The time series of $\left[\mathrm{O}_{3}\right]$ of the relative contributions to Phoenix $\left[\mathrm{O}_{3}\right]$ from SoCal and $\mathrm{AZ}$ emissions exhibit a diurnal variation. During nighttime hours, the transported ozone increases $\left[\mathrm{O}_{3}\right]$ while local $\mathrm{NO}_{x}$ emissions consume it. The reverse occurs during afternoon hours when locally generated emissions predominate.

WRF-chem's high resolution resolves all pertinent topographical features, especially the critical low-elevation mountain passes, capturing the pollutant transport through them. Therefore, the pollutant's (mainly ozone) transport pathway in the lower troposphere is identified: the pollutants (mainly ozone) are first transported to the southern Mojave Desert Air Basin (SMDAB) and the Salton Sea Air Basin (SSAB) through both the Mountain Chimney Effect (MCE) and Mountain Pass Channel Effect (PCE) during daytime, affecting DMA8 $\left[\mathrm{O}_{3}\right]$ in these two air basins. The following physical transport paths (based on the two events) are: the pollutants are first transported southeastward along the two air basins (the SSAB and the SMDAB) in CA during nighttime, then northeastward along the Gila River basin in AZ during nighttime, and finally reach the Phoenix area and mix with the local air mass by turbulent mixing during daytime. The entire transport path is determined by a combination of local and synoptic circulations.

Since the PBL height can extend in excess of 3-4 km a.g.l. in desert air basins, pollutants may be directly transported into the daytime desert PBL from coasts by both PCE and MCE. Therefore, regional transport in the desert is accomplished in the PBL (daytime), and residual layer and stable PBL (nighttime).

\section{The Supplement related to this article is available online at doi:10.5194/acp-15-9345-2015-supplement.}

Acknowledgements. This work has been funded by National Science Foundation grants DMS-1419593 and EAR-1204774, and USDA NIFA grant 2015-67003-23508. We thank the Julie Ann Wrigley Global Institute of Sustainability at Arizona State University for valuable support. The authors appreciate the comments and suggestions from Steven Peckham (NOAA). Chun Zhao (PNNL) and Xiaohong Liu (University of Wyoming) have also shared their successful experiences with the first author. We are grateful to Kirk Baker (EPA) and the other reviewer for the comments and suggestions.

Edited by: S. Brown

\section{References}

Ackermann, I., Hass, H., Memmesheimer, M., Ebel, A., Binkowski, F., and Shankar, U.: Modal aerosol dynamics model for Europe: Development and first applications, Atoms. Environ., 32, 29812999, 1998.

Adams, D. and Comrie, A.: The North American monsoon, Bill. Am. Meteorol. Soc., 78, 2198-2213, 1997.

Anderson, H.: Air pollution and mortality: A history, Atmos. Environ., 43, 143-152, doi:10.1016/j.atmosenv.2008.09.026, 2009.

Ashmore, M.: Assessing the future global impacts of ozone on vegetation, Plant Cell Environ., 29, 949-964, doi:10.1111/j.13653040.2005.01341.x, 2005.

Avnery, S., Mauzeral, D., Liu, J., and Horwiz, W. : Global crop yield reductions due to surface ozone exposure: 1: Year of 2000 crop production losses and economic damage, Atmos. Eviron., 45, 228-4-2296, 2011.

Bowman, K.: Toward the next generation of air quality monitoring: Ozone, Atmos. Environ., 80, 571-583, 2013.

Chameides, W., Li, X., Tang, X., Zhou, X, Luo, C., Kiang, C., St John, J., Saylor, R., Liu, S., Lam, K., Wang, T., and Giorgi, F. : Is ozone pollution affecting crop yields in China?, Geophys. Res. Lett., 26, 867-870, doi:10.1029/1999g1900068, 1999.

Chen, D., Li, Q., Stutz, J., Mao, Y., Zhang, L., Pikelnaya, O., and Tsai, J.: WRF-Chem simulation of $\mathrm{NO}_{x}$ and $\mathrm{O} 3$ in the LA basin during CalNex 2010, Atmos. Environ., 81, 421-432, 2013.

Chen, F. and Dudhia, J.: Coupling an Advanced Land Surface Hydrology Model with the Penn State NCAR MM5 Modeling System. Part 1: Model Implementation and Sensitivity, Mon. Weather Rev., 129, 569-585, 2001.

Chen, F., Kusaka, H., Bornstein, R., Ching, J., Grimmond, C., Grossman-Clarke, S., Loridan, T., Manning, K., Martilli, A., Miao, S., Sailor, D., Salamanca, F., Taha, H., Tewari, M., Wang, X., Wyszogrodzki, A., and Zhang, C.: The integrated WRF/urban modeling system: development, evaluation, and applications to urban environmental problems, Int. J. Climatol., 31, 273-288, doi:10.1002/joc.2158, 2011.

Croes, B. and Fujita, E.: Overview of the 1997 southern California ozone study(SCOS97-NARSTO), Atmos. Environ., 37, 3-26, doi:10.1016/S1352-2310(03)00379-0, 2003.

Ek, M., Mitchell, B., Lin, K., Rogers, Y., Grunmann, E., Koren, P., Gayno, V., and Tarpley, J.: Implementation of Noah land surface model advances in the National Centers for Environmental Prediction operational mesoscale Eta Model, J. Geophys. Res., 108, 8851, doi:10.1029/2002JD003296, 2003.

Emmons, L. K., Walters, S., Hess, P. G., Lamarque, J.-F., Pfister, G. G., Fillmore, D., Granier, C., Guenther, A., Kinnison, D., Laepple, T., Orlando, J., Tie, X., Tyndall, G., Wiedinmyer, C., Baughcum, S. L., and Kloster, S.: Description and evaluation of the Model for Ozone and Related chemical Tracers, version 4 (MOZART-4), Geosci. Model Dev., 3, 43-67, doi:10.5194/gmd3-43-2010, 2010.

EPA: National Ambient Air Quality Standards for Ozone, available at: http://www.epa.gov/glo/pdfs/20141125proposal.pdf (last access: 12 August 2015), 2014.

Fast, J., Doran, J., and Shaw, W.: The evolution of the boundary layer and its effect on air chemistry in the Phoenix area, J. Geophys. Res., 105, 22833-22848, 2000.

Fast, J., Zaveri, D., Bian, X., Chapman, E., and Easter, R.: Effect of regional-scale transport on oxidants in the vicinity of Philadel- 
phia during the 1999 NE-OPS field campaign, J. Geophys. Res., 107, 4307, doi:10.1029/2001JD000980, 2002.

Friedl, M., McIver, D., Hodges, F., Zhang, X., Muchnoey, D., Strahler, A., Woodcock, C., Gopal, S., Schneider, A., Cooper, A., Baccini, A., Gao, F., and Schaaf, C.: Global land cover mapping from MODIS: algorithms and early results, Remote Sens. Environ., 83, 287-302, 2002.

Ginoux, P., Chin, M., Tegen, I., Prospero, J., Holben, B., Dubovik, O., and Lin, S.-J.: Sources and global distributions of dust aerosols simulated with the GOCART model, J. Geophys. Res., 106, 20255-20273, 2001.

Grell, G. and Devenyi, D.: A generalized approach to parameterizing convection combining ensemble and data assimilation techniques, Geophys. Res. Lett., 29, 4 pp., doi:10.1029/2002GL015311, 2002.

Grell, G., Peckham, S., Schmitz, R., McKeen, S., Frost, G., Skamarock, W., and Eder, B.: Fully coupled "online" chemistry within the WRF model, Atmos. Environ. 39, 6957-6975, doi:10.1016/j.atmosenv.2005.04.027, 2005.

Gross, A. and Stockwell, W.: Comparison of the EMEP, RADM2 and RACM mechanisms, J. Atmos. Chem., 44, 151-170, 2003.

Guenther, A., Karl, T., Harley, P., Wiedinmyer, C., Palmer, P. I., and Geron, C.: Estimates of global terrestrial isoprene emissions using MEGAN (Model of Emissions of Gases and Aerosols from Nature), Atmos. Chem. Phys., 6, 3181-3210, doi:10.5194/acp-63181-2006, 2006.

He, H., Stehr, J. W., Hains, J. C., Krask, D. J., Doddridge, B. G., Vinnikov, K. Y., Canty, T. P., Hosley, K. M., Salawitch, R. J., Worden, H. M., and Dickerson, R. R.: Trends in emissions and concentrations of air pollutants in the lower troposphere in the Baltimore/Washington airshed from 1997 to 2011, Atmos. Chem. Phys., 13, 7859-7874, doi:10.5194/acp-13-7859-2013, 2013.

Huang, M., Bowman, K., Carmichael, G., Pierce, B., Worden, H., Lou, M., Cooper, O., Pollack, I. Ryerson, T., and Brown, S.: Impact of Southern California anthropogenic emissions on ozone pollution in the mountain states: Model analysis and observational evidence from space, J. Geophys. Res-Atmos., 118, 12784-12803, 2013.

Hovmoller, E.: The trough-and-Ridge diagram, Tellus, 1, 62-66, 1949.

IPCC: Climate change: The physical science basis, contribution of Working Group I to the Fourth Assessment Report (AR4) of the Intergovemental Panel on Climate Change, 996 pp., 2007.

Kemball-Cook, S., Parrish, D., Ryerson, T., Nopmongool, U., Johnson, J., Tai, E., and Yarwood, G.: Contributions of regional transport and local sources to ozone exceedances in Houston and Dallas: Comparison of results from a photochemical grid model to aircraft and surface measurement, J. Geophys. Res., 114, D00F02, doi:10.1029/2008JD010248, 2009.

Klich, C. A. and Fuelberg, H. E.: The role of horizontal model resolution in assessing the transport of $\mathrm{CO}$ in a middle latitude cyclone using WRF-Chem, Atmos. Chem. Phys., 14, 609-627, doi:10.5194/acp-14-609-2014, 2014.

Kwok, R. H. F., Baker, K. R., Napelenok, S. L., and Tonnesen, G. S.: Photochemical grid model implementation and application of VOC, $\mathrm{NO}_{x}$, and $\mathrm{O}_{3}$ source apportionment, Geosci. Model Dev., 8, 99-114, doi:10.5194/gmd-8-99-2015, 2015.
Langford, A., Senff, C., Alvarez, R., Banta, R., and Hardesty, R.: Long-range transport of ozone from the Los Angeles Basin: A case study, Geophys. Res. Lett., 37, L06807, doi:10.1029/2010GL042507, 2010.

Lawson, D.: The southern California air quality study, J. Air Waste Manage. Assoc., 40, 156-165, 1990.

Lee, S. and Fernando, H.: Dispersion of an urban photochemical plume in Phoenix metropolitan area, Atmos. Environ., 80, 152160, 2013.

Lee, S., Fernando, H., Princevac, M., Zajic, D., Sinesf, M., Mcculley, J., and Anderson, J.: Transport and diffusion of ozone in the nocturnal and morning planetary boundary layer of the Phoenix Valley, Environ. Fluid Mech., 3 331-362, 2003.

Lee, S., Fernando, H., and Grossman-Clarke, S.: MM5-SMOKECMAQ as a modeling tool for 8-h ozone regulatory enforcement: application to the state of Arizona, Environ. Model. Assess., 12, 63-74, 2007.

Levy II, H., Mahlman, J., Moxim, W., and Liu, S.: Tropospheric Ozone: The role of transport, J. Geophys. Res., 90, 3753-3772, 1985.

Li, J., Georgescu, M., Hyde, P., Mahalov, A., and Moustaoui, M.: Achieving accurate simulations of urban impacts on ozone at high resolution, Environ. Res. Lett. 9, 114019, doi:10.1088/1748-9326/9/11/114019, 2014

Lin, M., Fiore, A., Horowitz, L., Cooper, O., Naik, V.,Holloway, J., Johnson, B., Middlebrook, A., Oltmans, S., Pollack, I., Ryerson, T., Warner, J., Wiedinmyer, C., Wilson, J., and Wyman, B.: Transport of Asian ozone pollution into surface air over the western United States in Spring, J. Geophys. Res., 117, D00V07, doi:10.29/2011JD016961, 2012.

Lin, Y., Farley, R., and Orville, H.: Bulk parameterization of the snow field in a cloud model, J. Climate Appl. Meteor., 22, 10651092, 1983.

Lu, R. and Turco, R.: Air pollution transport in a coastal environment: Part II: Three-dimensional simulations of sea-breeze and mountain effect, Atmos. Environ., 29B, 1499-1518, 1995.

Lu, R. and Turco, R.: Ozone distributions over the Los Angeles Basin: Three-dimensional simulations with the SMOG model, Atmos. Environ., 30, 4155-4176, 1996.

Lu, R., Turco, R., and Jacobson, M.: An integrated air pollution modeling system for urban and regional scales: 2: Simulations for SCAQS 1987, J. Geophys. Res., 102, 6081-6098, 1997.

MacDonald, C., Miller, D., and Raffuse, D.: Regional and local contributions to peak local ozone concentrations in six western cities, Final Report for Western States Air Resources Council (WESATR), STI-906004-2970-FR, Sonoma Technology, Inc., available at: www.sonomatech.com (last access: June 2014), 2006.

Mauzerall, D. and Wang, X.: Protecting agricultural crops from the effects of tropospheric ozone exposure: Reconciling science and standard setting in the United States, Europe, and Asia, Ann. Rev. Energy Environ., 26, 237-268, 2001.

Mesinger F., DiMego, G., Kalney, E., Mitchell, K., Shafran, P., Ebisuzaki, W., Jovic, D., Woollen J., Rogers, E., Berbery, E., Ek, M., Fan, Y., Grumbine, R., Higgins, W., Li, H., Lin, Y., Manikin, G., Parrish, D., and Shi, W.: North American regional reanalysis, Bull. Amer. Meteor. Soc., 87, 343-360, 2006.

Mlawer, E., Taubman, S., Brown, P., Iacono, M., and Clough, S.: Radiative transfer for inhomogeneous atmospheres: RRTM, a 
validated correlated-k model for the longwave, J. Geophy. Res.Atmos., 102, 16663-16682, 1997.

Moore, T.: Ozone 301, Maricopa County Air Quality Department, September 4, 2014, available at: http://www.wrapair2.org/pdf/ Ozone301MCAQDSept4_2014noanimation.pdf, 2014.

Nunnermacker, L., Weinstein-Lloyd, J., Kleinman, L., Daum, P., Lee, Y., Springston, S., Klotz, P., Newman, L., Neuroth, G., and Hyde, P.: Ground-based and aircraft measurements of trace gases in Phoenix, Arizona (1998), Atmos. Environ., 38, 4941-4956, 2004.

Peckam, S., Grell, G., McKeen, S., Ahmadov, R., Barth, M., Pfuster, G., Wiedinmyer, C., Fast J Gustat]fason, W., Ghan, S., Zaveri, R., Easter, R., Barnard, J., Chapman, E., Hewson, M., Schmitz, R., Salzmann, M., Beck, V., Freitas, S., Previsao de, C., and Estudos, T.: WRF/CHEM Version 3.5 User's Guide, available at: ruc.noaa. gov/wrf/WG11/Usersguide.pdf, last access: 12 February 2013.

Pusede, S. E. and Cohen, R. C.: On the observed response of ozone to NOx and VOC reactivity reductions in San Joaquin Valley California 1995-present, Atmos. Chem. Phys., 12, 8323-8339, doi:10.5194/acp-12-8323-2012, 2012.

Schell, B., Ackermann, I., Hass, H., Binkowski, F., and Ebel, A.: Modeling the formation of secondary organic aerosol with a comprehensive air quality modeling system, J. Geophys. Res., 106, 28275-28293, 2001.

Simon, H., Baker, K., and Phillips, S.: Compilation and interpretation of photochemical model performance statistics published between 2006 and 2012, Atmos. Environ., 61, 124-139, 2012.

Skamarock, W., Klemp, J., Dudhia, J., Gill, D., Barker, D., Wang, W., and Powers, J.: A description the Advanced Research WRF version 3, available at: http://www2.mmm.ucar.edu/wrf/users/ docs/arw_v3.pdf, 2008.

Smith, K., Jerrett, M., Anderson, R., Burnett, R., Stone, V., Derwent, R., Atkinson, R., Cohen, A., Shonko, S., Krewski, D., Pope, III, A., Thun, M., and Thurston, G.: Public benefits of strategies to reduce greenhouse-gas emissions: Health implications of short-lived greenhouse pollutants, Lancet, 374, 9707, doi:10.1016/S0140-6737(09)61716-5, 2009.
Stock, Z. S., Russo, M. R., and Pyle, J. A.: Representing ozone extremes in European megacities: the importance of resolution in a global chemistry climate model, Atmos. Chem. Phys., 14, 3899-3912, doi:10.5194/acp-14-3899-2014, 2014.

Stockwell, W., Middleton, P., Chang, J., and Tang, X.: The Second Generation Regional Acid Deposition Model Chemical Mechanism for Regional Air Quality Modeling, J. Geophys. Res., 95, 16343-16367, 1990.

Taha, H.: Urban surface modification as a potential ozone airquality improvement strategy in California: A mesoscale modeling study, Bound.-Lay. Meteorol., 127, 219-239, 2008.

Taha, H., Konopacki, S., and Akbari, H.: Impacts of lowered urban air temperature on precursor emission and ozone air quality, J. Air Waste Manage. Assoc., 48, 860-865, 1998.

Tie, X., Brasseur, G., and Ying, Z.: Impact of model resolution on chemical ozone formation in Mexico City: application of the WRF-Chem model, Atmos. Chem. Phys., 10, 8983-8995, doi:10.5194/acp-10-8983-2010, 2010.

VanCuren, R.: transport aloft drivers peak ozone in the Mojave Desert, Atmos. Environ., 109, 331-341, doi:10.1016/j.atmosenv.2014.09.057, 2015.

Zhao, C., Liu, X., Leung, L. R., Johnson, B., McFarlane, S. A., Gustafson Jr., W. I., Fast, J. D., and Easter, R.: The spatial distribution of mineral dust and its shortwave radiative forcing over North Africa: modeling sensitivities to dust emissions and aerosol size treatments, Atmos. Chem. Phys., 10, 8821-8838, doi:10.5194/acp-10-8821-2010, 2010.

Zhao, C., Liu, X., and Leung, L. R.: Impact of the Desert dust on the summer monsoon system over Southwestern North America, Atmos. Chem. Phys., 12, 3717-3731, doi:10.5194/acp-12-37172012, 2012. 